بسم اللألرحن الرحيم.

\title{
أثر البيئة البلدوية في مصطلحات الخليل العروضية
}

\author{
د/ الحسن المثنى عمر الفاروق \\ مدير جامعة أم درمان الإسلامية فرع نيالا
}


ظهر الاهتمام بالمعنى الاصطلاحي باكراً في الحضارة

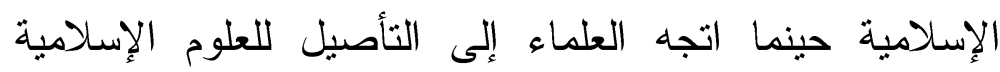
بمختلف مسمياتها ، و لا يخرج الحديث عن المعنى الاصطلاحي عن التطور الدلالي الذي صاحب ألفاظ اللغة العربية بسبب ظهور الإسلام، حيث خرجت الكثير من الألفاظ عن معانيها اللغوية لتحمل معاني استجدت بسبب النقلة الدينية و السياسة و الاجتماعية التي حدثت في المجتمع العربي والإسلامي ، و على ذلك فإن العلوم الإسلامية المختلفة سواء أكانت في الشريعة و الدين أم الأدب و اللغة ، كانت تتص في مباحثها المختلفة على أمرين: الأول: هو المعنى اللغوي الموضوع للفن في أصل الادب ولابله اللغة، و الثاني: المعنى الاصطلاحي الذي نُقلت إليه اللفظة في استعمال جديد اصطلح عليه أهل فن علمي معين. وعلم العروض لم يخرج عن هذا المنحى ، فقد وضعه الخليل بن أحمد الفر اهيدي ووضع مصطلحاته وابتكر مباحثه ، وما يميز هذا العلم عن بقية العلوم في نشأته أنه أتفق على ولى أن و اضعه شخص واحد هو الخليل ، على حين اختلف الناس في و اضعي العلوم الأخرى ، كالنحو مثناً نجد مصطلحاته متعددة فالمصطلح الواحد يحمل أكثر من اسم كمصطلحات نحاة الكوفة التي تختلف عن مصطلحات نحاة البصرة ، ولعل انفراد الخليل بهذا العلم قد ساعد في أن تتخذ مصطلحاته شكلاً يخالف ما عليه الحال في مصطلحات العلوم الأخرى ، ويبدو أن شخصية الخليل ومقدراته العالية في الابتكار وبقاؤه في البادية زمناً 
طويلاً ، قد أثر فيه فعقد مصطلحاته معندداً على البيئة البدوية التي عاش فيها وخبر ها.

حاول هذا البحث تتبع مصطلحات الخليل في علم

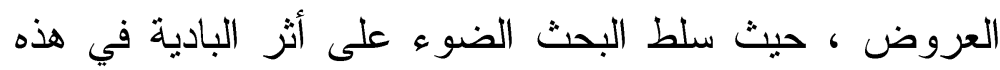

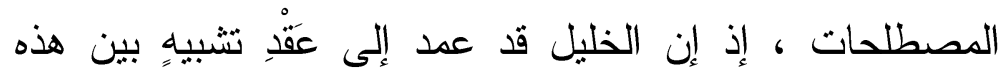

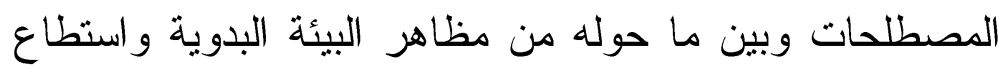
أن يخلق شكلاً من التلاقي بين المدلول اللغوي للكلمة مع مدلولها الاصطلاحي ، وقد مثلت البادية نقطة التلاقي بين هذين المدلولين ، وقد اتخذ الخليل من موجودات البادية صوراً

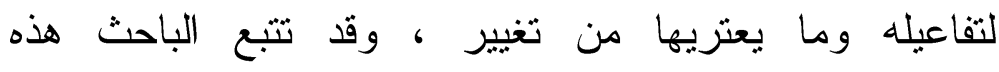
المصطلحات وصنفها إلى مصطلحات مشبّهة بمسكن إنسان

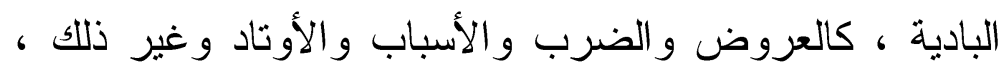

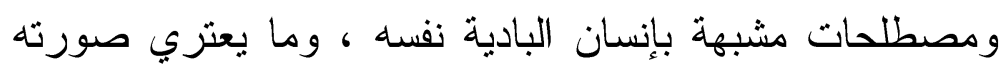

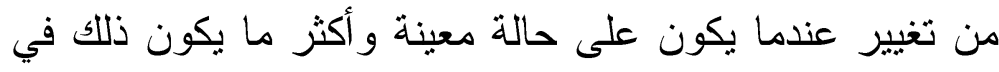

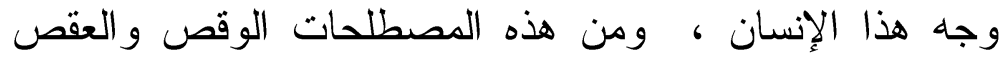
و الخرم و التلم وغيرها ، كما لحق هذا التنبيه ما يصيب الإنسان

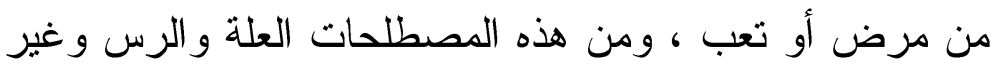
ذللك مما أثار إليه الباحث في موضعن ، ودن هذه البه البحث ، وهناك مصطلحات أخرى لها تعلق بثوب البدوي كالكف والتذييل

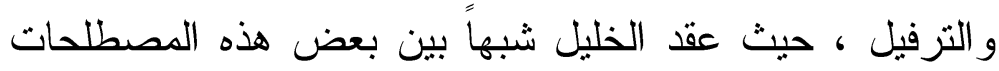
وبين ثوب البدوي حينما يخبن أو يكف أو يذيل. ولم يخفل الخليل

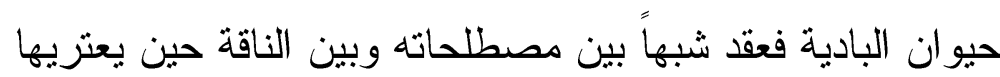

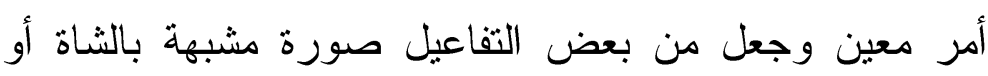


الفرس ، ومن هذه المصطلحات الزحاف و العصب و العضب و الجمم والخزم و غير ذلك. ولعل اتجاه الخليل إلى البيئة البدوية وعقد شبه بين مصطلحاته وبين مظاهر ها له سببه الوجيه المتمثل في محاولته

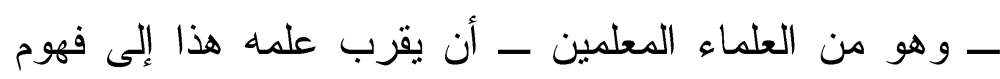
متعلميه فوجد في معطبات البادية صورة ذهنية تقرب التغيير

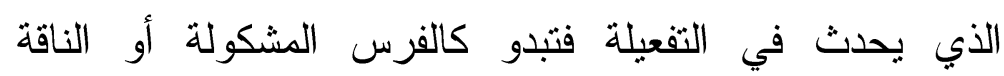

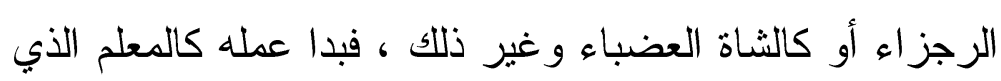
يصمم وسيلة تعليمية ويرسمها في صورة ذهنية راسخة في ذهن كل من عاش بالبادية ، و وعلى هذا جاءت مصطلحات الخليل

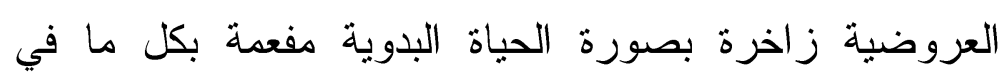

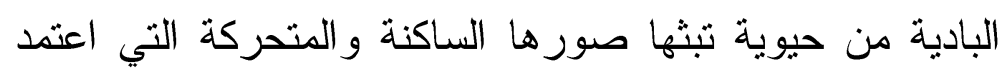

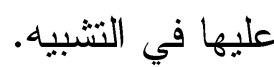
نشأة علم العروض:

بالنظر إلى حياة العرب في ماضي جاهليتهم وصدر

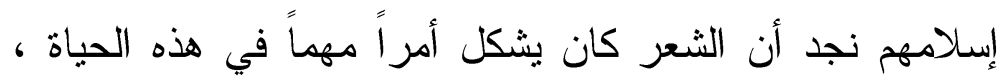
فهو فنهم الذي ألفوه ، ومجالهم الذي أبدعوا فيه ونوارثوه كابراً

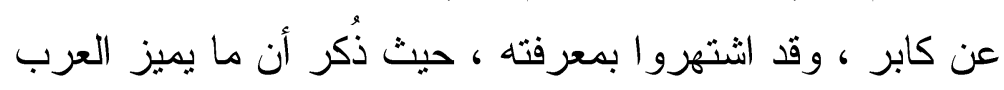

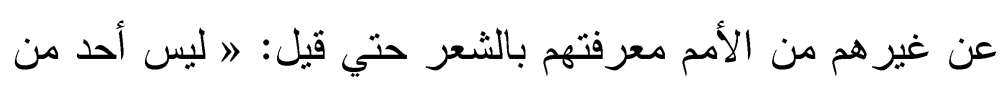

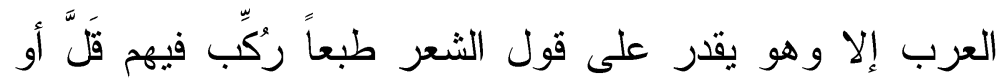

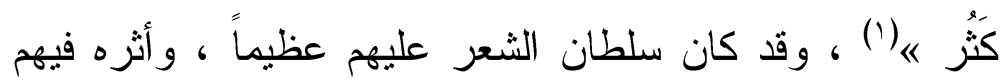

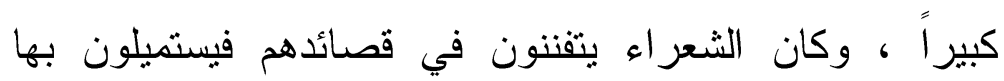

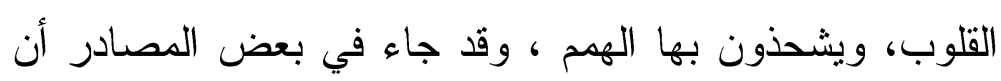

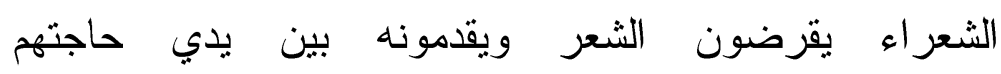


》فيستتـزلون به الكريم ويستعطفون به اللائمه(؟)، ولفرط أثره

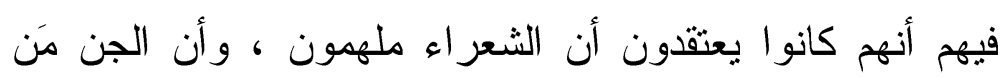

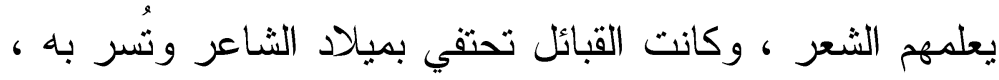

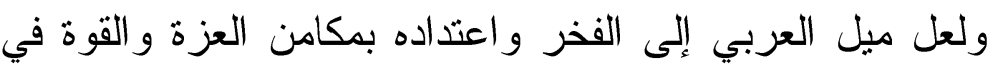

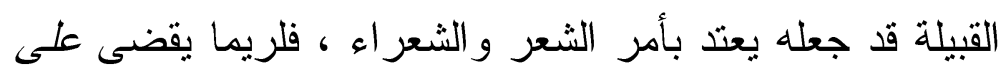

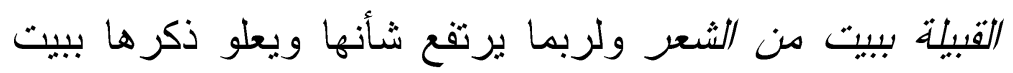
آخر ()، وقد مثّل الشعر ذاكرة للقبيلة وكتاباً لأيامها و وعاداتها

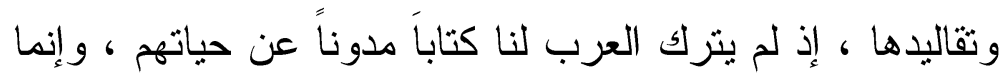

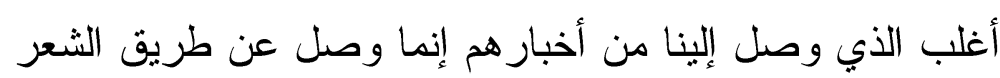

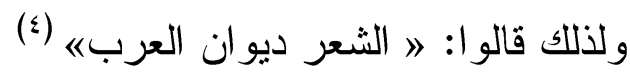

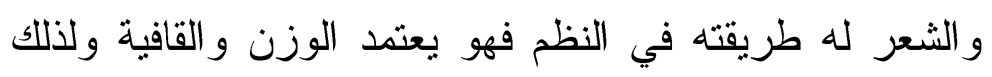

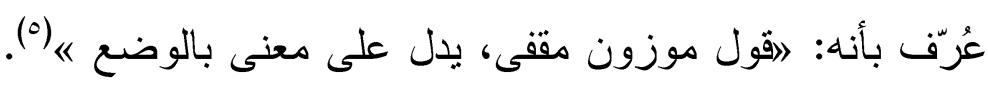

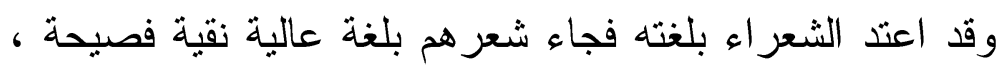

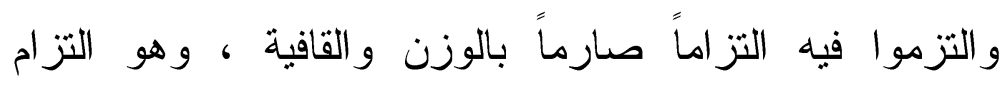
اضطرهم إلى الخروج على بعض مقاييس كلامهم فصار

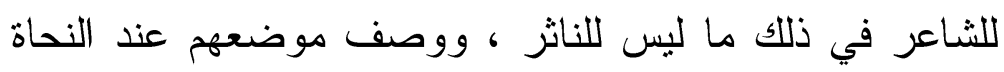

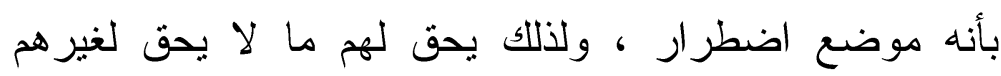

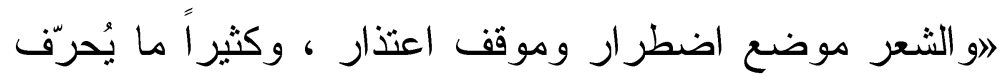

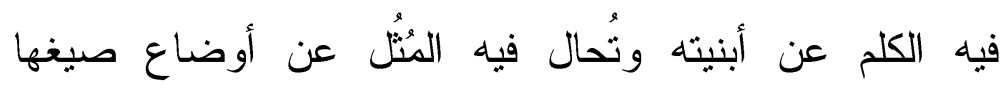

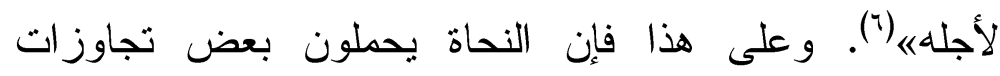

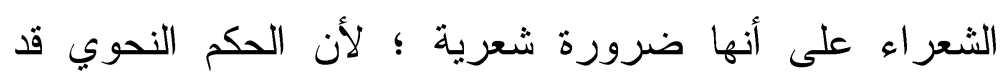

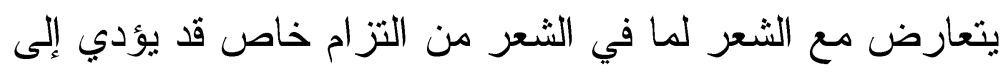
الخروج عن هذا الحكم النحوي ، ولذلك فإنهم قسموا الحكم النحوي إلى رخصة وغيرها ، و الرخصة في الحكم النحوي 
تتعلق بالثعر ، فللثاعر أن يحدث بعض التعديلات في التركيب، وهذا التعديل يجب أن يكون بمقدار وإلا عُدَّ خطاً

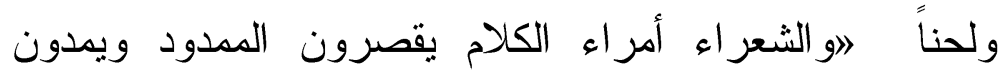
المقصور ، يقدّمون ويؤخرون ، ويومئون ويشيرون ، يختلسون

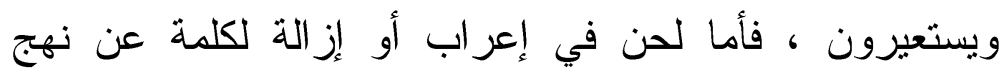

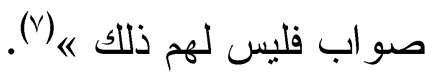

وقد كان اهنمام علماء العربية بالثعر عظيماً فقد مثّل

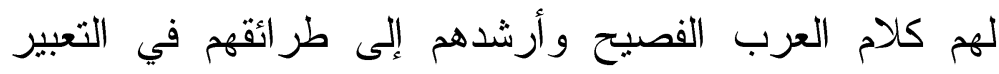
و أساليبهم في التركيب ، وكان معينهم في معرفة معاني الألفاظ ، وقد استدلوا به في كل دراساتهم اللغوية وبنوا على هديه قو اعدهم النحوية ، وقد وجد المفسرون في ألفاظه ما أسعفهم في ولي دئي

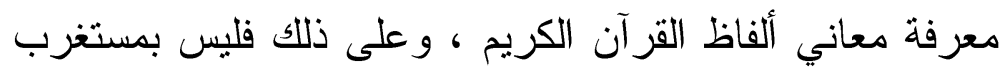

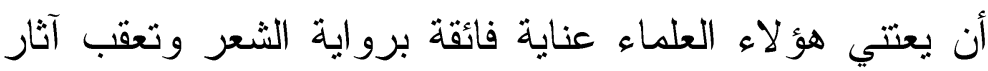
الشعر اء ، وقد نشطت رو ايته منذ وقت ليس بالقريب إذ كان

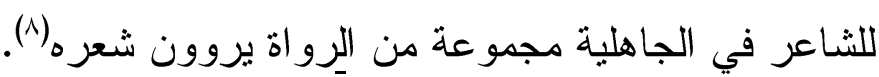
وعندما جاء الإسلام وتطرق اللحن إلى ألسن الناس

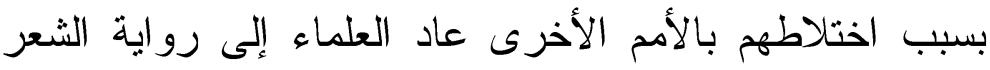
مرة أخرى ليعلموا الناس لغة العرب حيث شكل الثعر مصدراً للتقعيد والتطبيق ، وكان همهم الأكبر هو معرفة القرآن الكريم

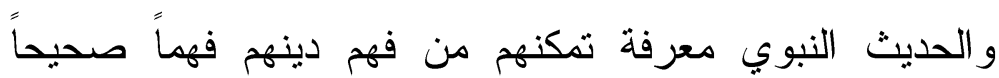

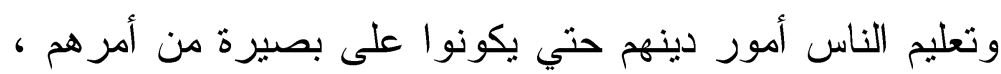

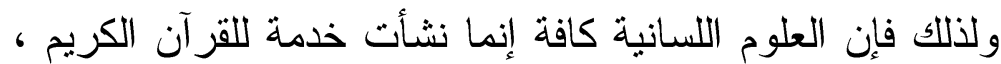
فكانت رواية الشعر للحصول على النصوص الفصيحة التي لإني يستال بها ويقاس عليها الكلام ، وقد شكل الشعر أهم هذه 
النصوص و اعتمدوا عليه اعتماداً كبيراً ، وامتذ بحثهم فيه

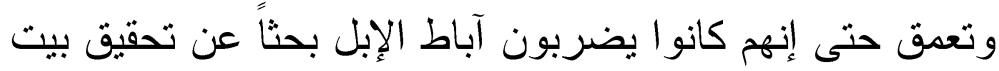

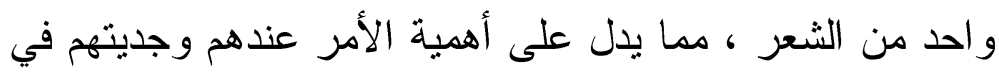

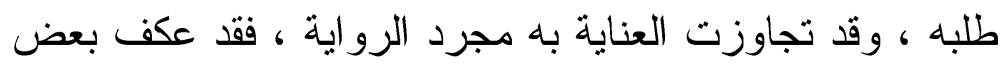

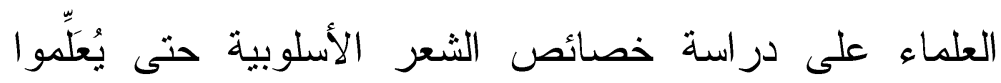

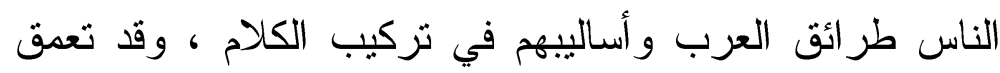

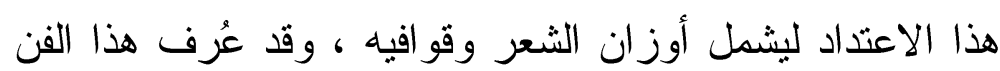

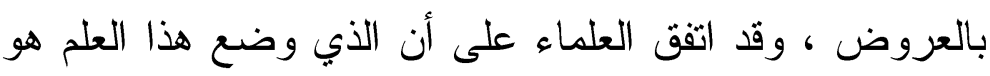

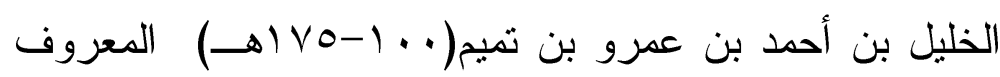

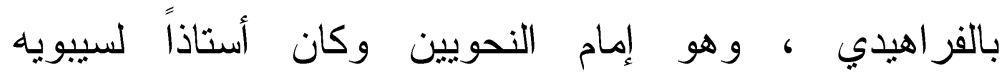

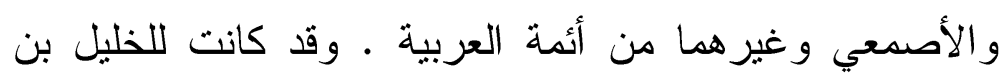
أحمد يده الطولى في وضع العلوم اللسانية كافة. وقد أفاد في وني

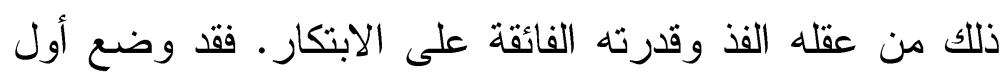

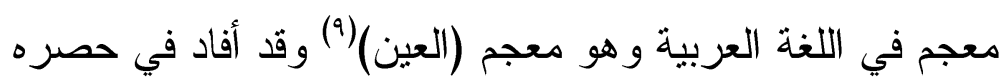
حصره لمادة هذا المعجم من معرفته بعلم الحساب و المنطق وقد

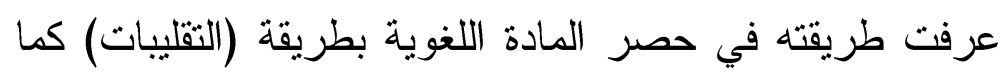

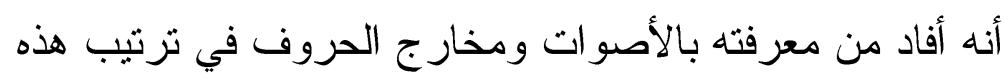

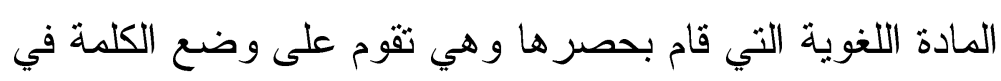

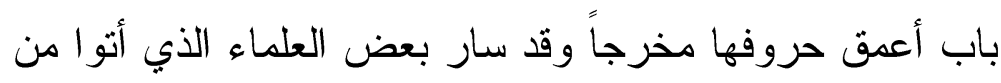

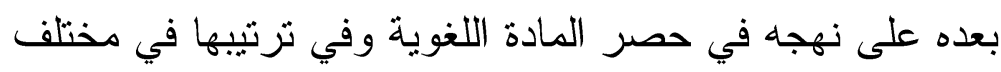
معاجمهر. وقد ذكرت كتب الثراجم أن الخليل كان رجلاً عاقلاً

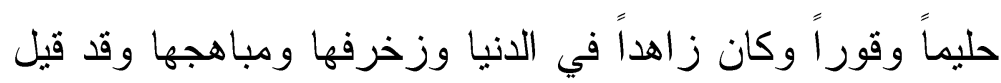

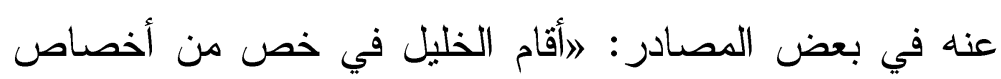


البصرة لا يقدر على فلسين و أصحابه يأكلون بعلمه

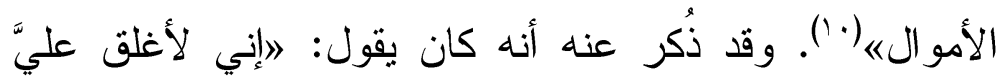

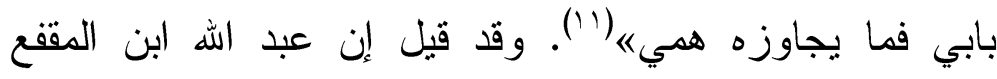

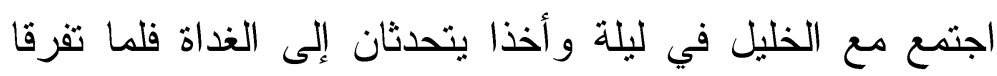
قيل لابن المقفع: كيف رأيت الخليل؟ قال: رأيت رجلاً عقله أكبر من علمه (IT)

وكان الخليل منهمكاً في الاختراع و الابتكار حتى آخر

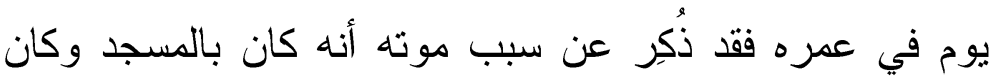

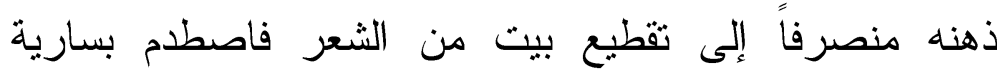
المسجد وهو غافل فانكفأ على ظهره فكان ذلك سبباً في موته. وقد جاء في روايات أخرى أن الخليل كان يفكر في ابتكار طريقة في الحساب تسهله على العامة حيث تمضي به الجارية

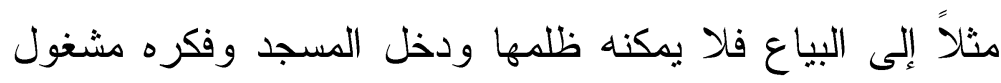
فصدمته سارية وهو غافل عنها بفكره فانقلب على ظهره فكانت

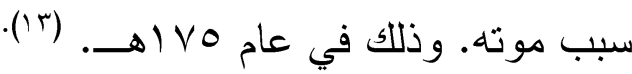
وقد اختلف العلماء في تعريف علم العروض ، ومن هذه

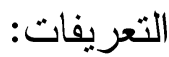

العروض: "علم يُعرف به صحيح الشعر من فاسده).(1 ()

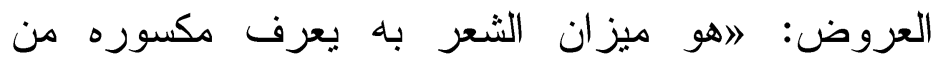
موزونهه.(10) العروض هو ميزان شعر العرب ، وبه يُعرف صحيحه من مكسوره 》افما وافق شعر العرب في عدة الحروف الساكن و المتحرك سمي شعراً وما خالفه فيما ذكرناه فليس بشعر هـ.(1") 


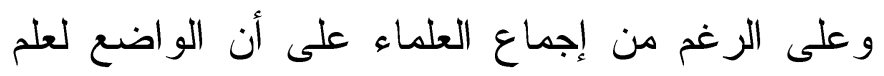
العروض هو الخليل ، إلا أنهم اختلفوا في السبب الذي من أجله

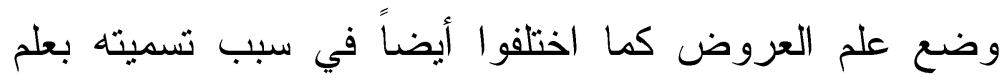
العروض ، ومن ذلك ما جاء في بعض المصادر أن الخليل دعا

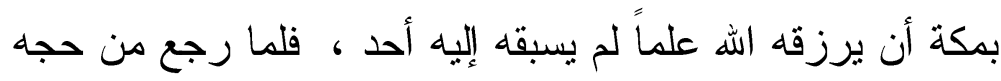

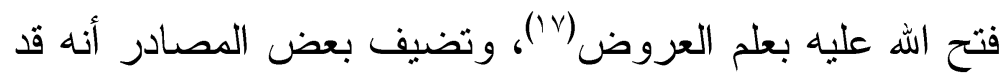
شق على الخليل ما أصاب تلميذه سيبويه من توفيق في مباحث

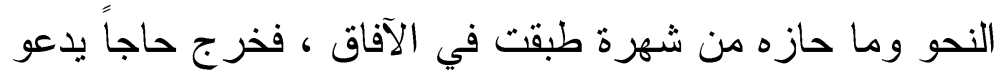

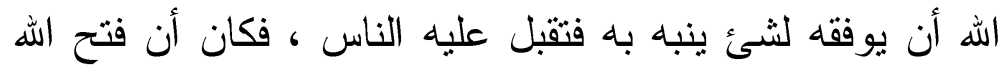

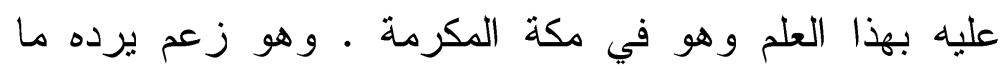

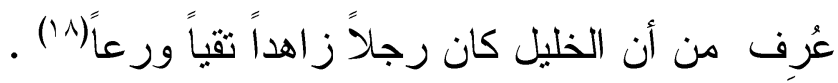

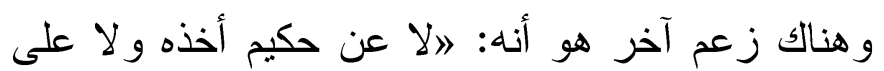
مثال تقدمه احتذاه و إنما اخترعه من ممر لله بالصفارينه

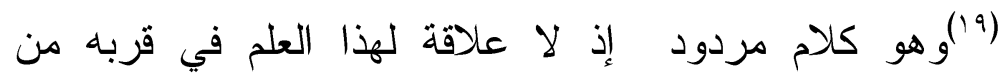

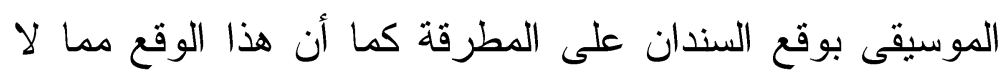

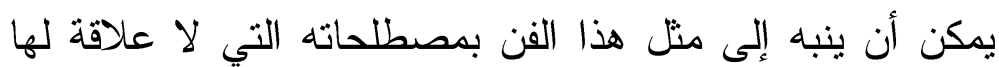

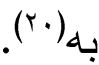

و هناك رواية أخرى تقول: إن الخليل سئل عن علم

العروض: ״اهل وجدت له أصلاً ؟ قال: نعم مررت بالن بالمدينة

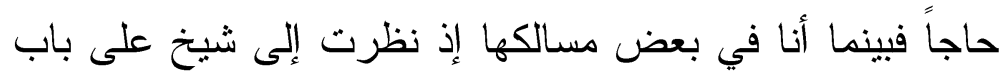

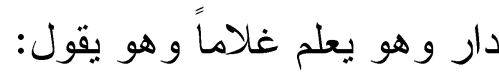

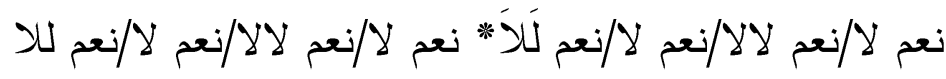

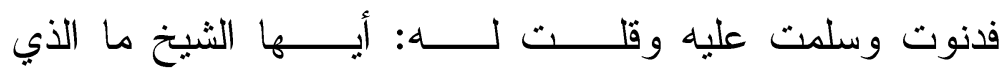

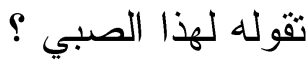


فقال: هذا علم يتوارثه هؤلاء عن سلفهم وهو عندهم يسمى

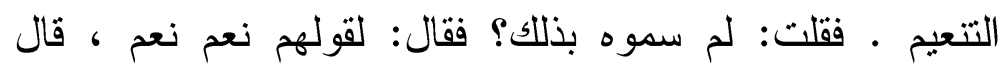

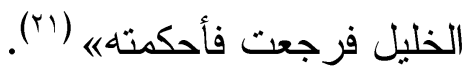
و هذه الرو اية أبضاً بردها إجماع معاصريه على أنى أنه أول من وضع هذا العلم. و الخليل في وضعه لهذا العلم إنما قام بملاحظة أوزان

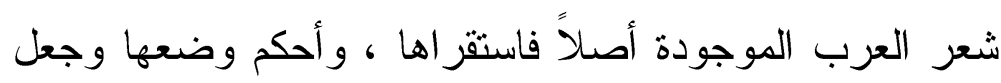

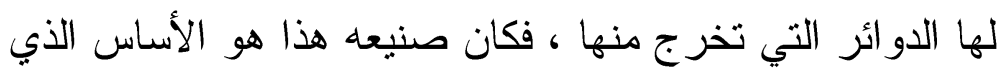

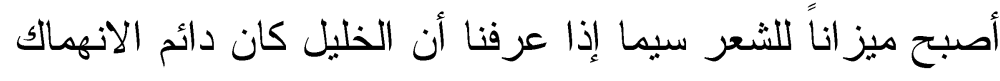
في الابتداع والاختراع ، وقد يكون علم الخليل بالأوزان الصرفية هو الذي نبهه إلى اتخاذ أوزان تماتلها في قئل فياس ملفوظات الشعر ومقابلة مقاطعه. وكان الخليل قد تجمعت لايه مجموعة كبيرة من الثعر

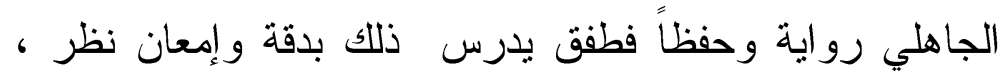

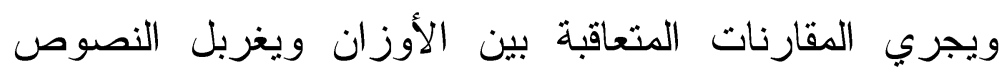

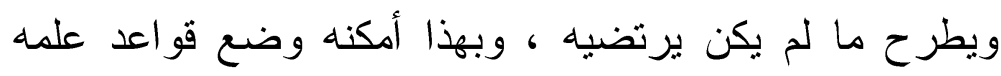
الجديد.

وقد اختلفت الروايات أيضاً في سبب تسمية هذا العلم

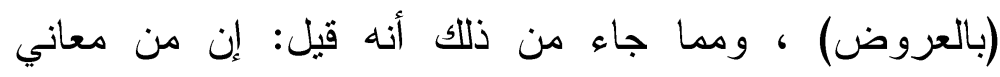

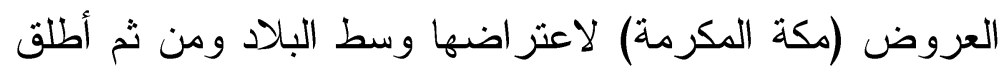

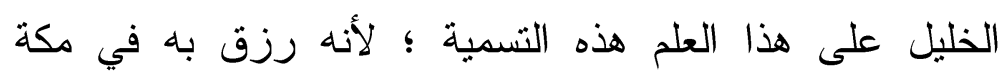

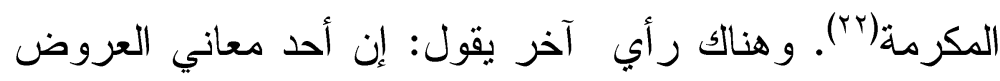

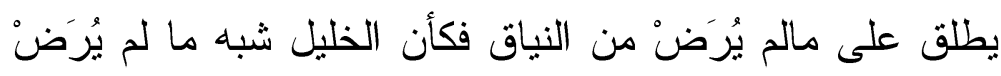

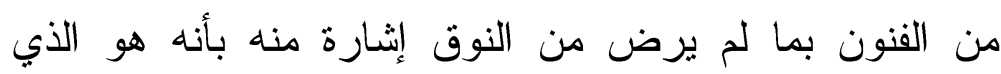


راضه(rr). وقد جاء أيضاً أن العروض سمي بالعروض ؛ لأن

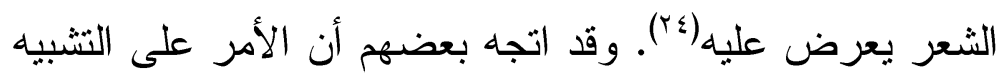

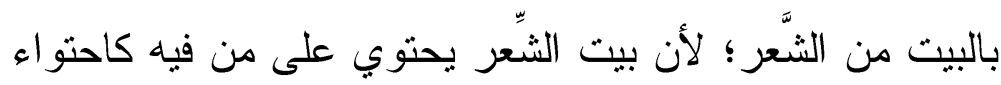

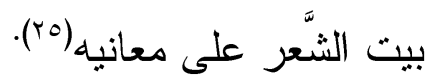
ولعل هذا الرأي يقارب ما نحن فيه من أن البادية قد

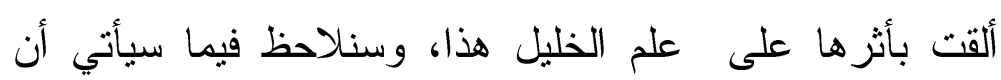

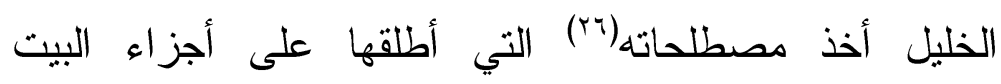

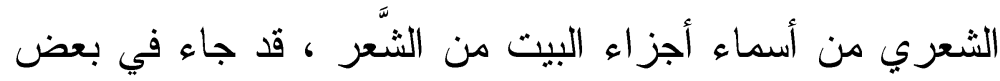

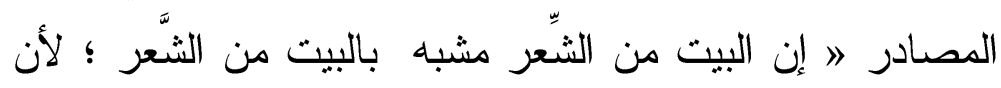

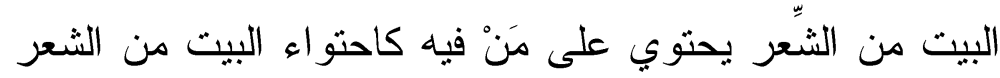
على معانيه. ولقد أحسن أبو العلاء في قوله:

والشعر يحسن في شيئين رونقه ^ بيت من الشُعر أو بيتّ من الشَعر

ولذلك سمى المقاطع التي تتكون منها التفاعيل بالأسباب

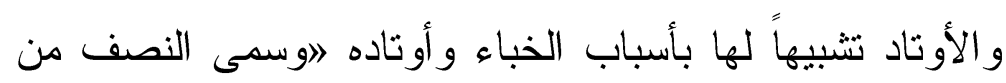

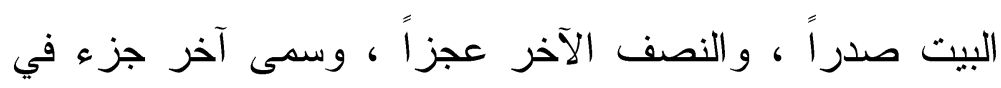

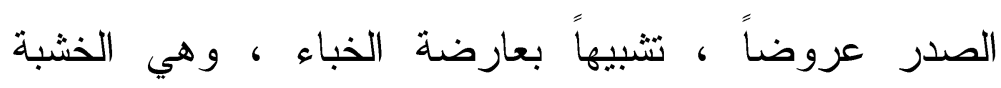

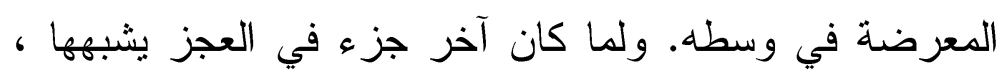

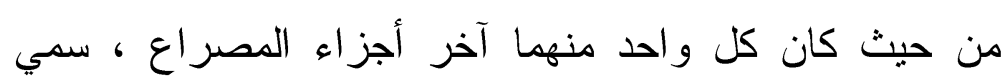

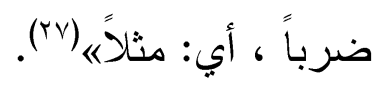

ولعله في هذا الذي ذُكر في النص السابق ما يقوّي الزعم بأن الخليل أفاد من البيئة البدوية التي عاش فئه في في وعرف

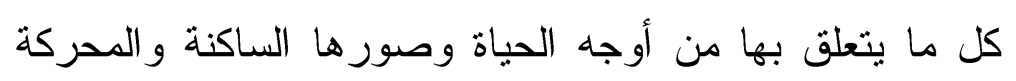

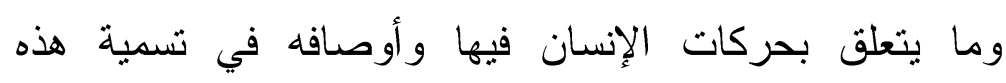


الدصطلحات ، حيث خلق نوعاً من العلاقة بين المصطلح و البيئة

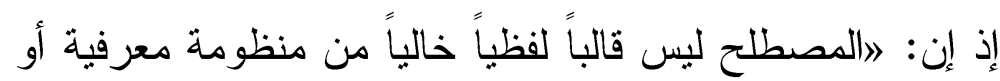

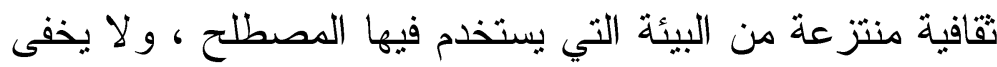

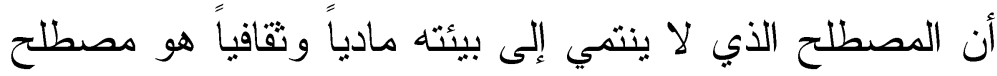

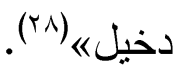
البادية وأثرها في مصطلحات الخليل:

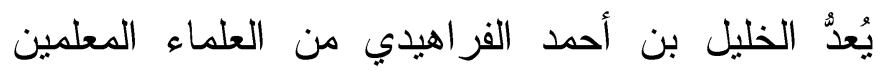

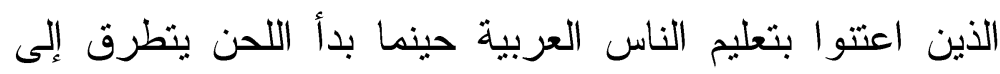

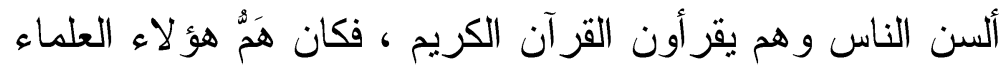
تعليم الناس أساليب العرب في التعبير وطر ائقهم في نركيب

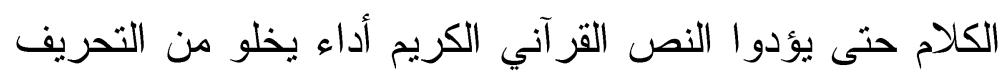

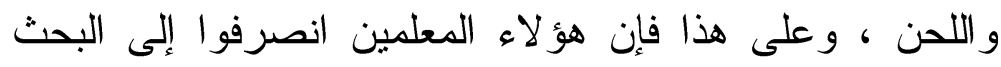
عن النصوص العربية الصحيحة الفصيحة ، ووضعوا ضوابط

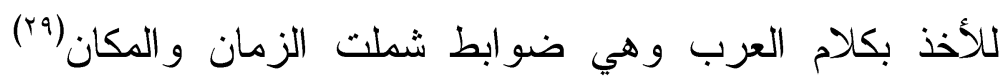

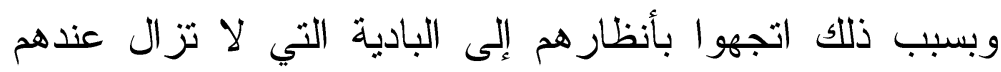
محتفظة بسليقتها اللغوية صحيحة فصيحة لم تؤثر فيها عوامل الزمن ، وقد كان الخليل من وجوه العلماء الذين اعتتو البالبادية

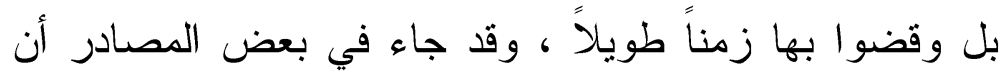

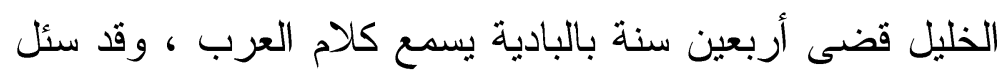

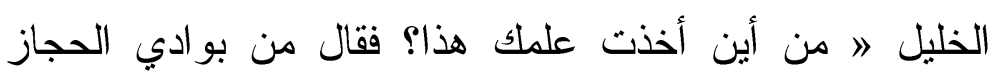

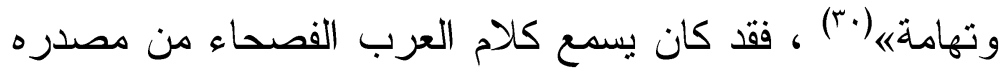

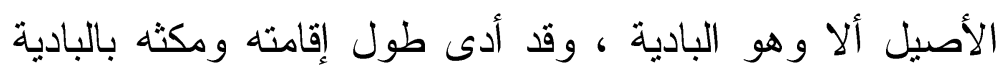

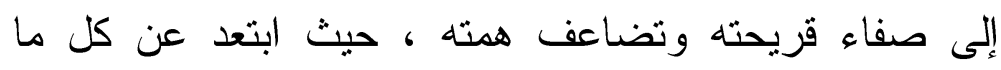


يشغله عن العلم ،وتفرّغ للعلم تفرّغاً تاماً ، ولعل ابتداع الخليل

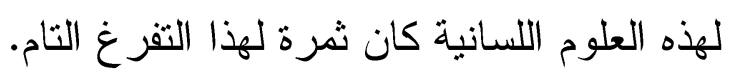

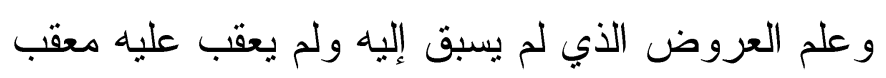

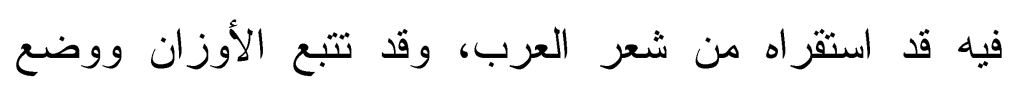
الدوائر العروضية التي عليها مدار الشعر العربي، ولعل البيئة

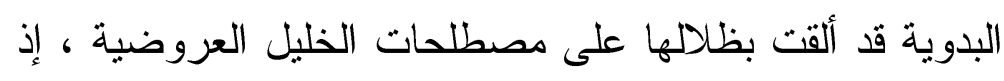

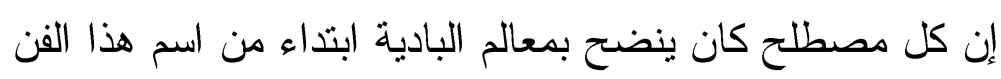

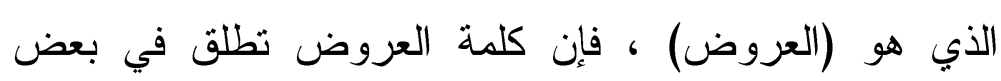

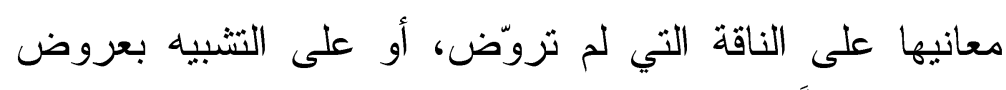

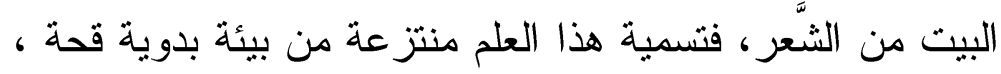
ويبدو أن الخليل قد جعل من مظاهر الحياة في البادية، وسيلة

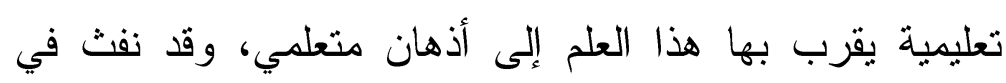

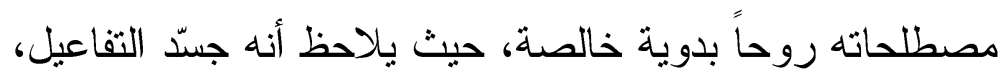

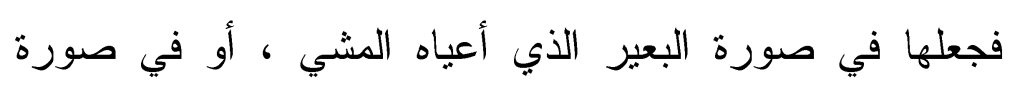

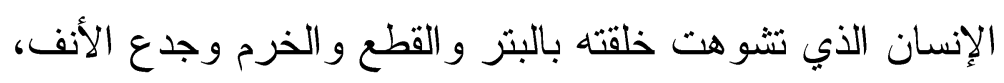
أو أن تمثّل التفعيلة في صورة الكبش الذي ليس لله قرن، وغير

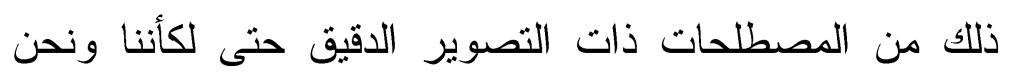

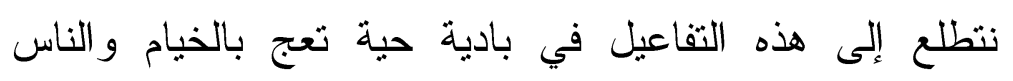

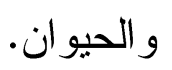

وليس غريباً أن يأتي الخليل بهذه الصورة وهذا التجسيد

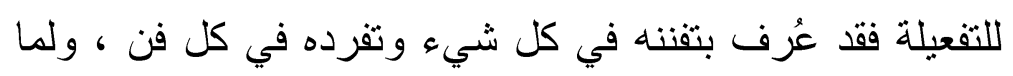

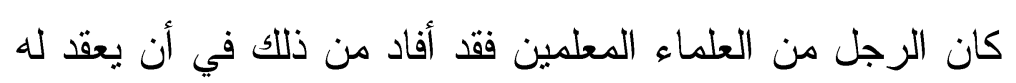

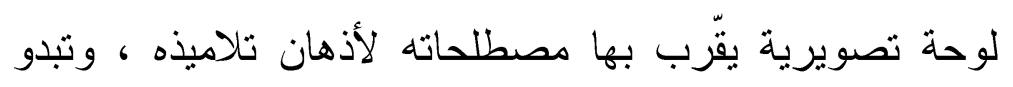

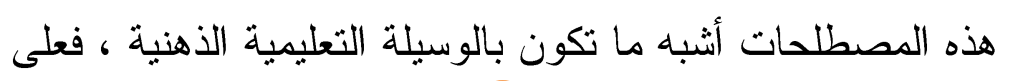


حين يعمد العلماء و المعلمون اليوم إلى استخدام وسيلة إيضاحية

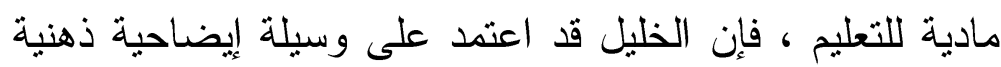
اعتمد فيها على معرفة الناس بمظاهر البادية و أثنكال مكوناتها

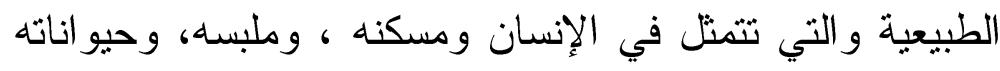

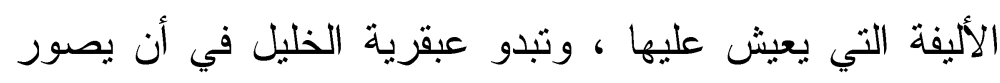

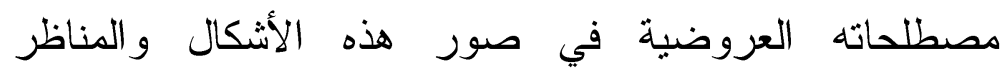

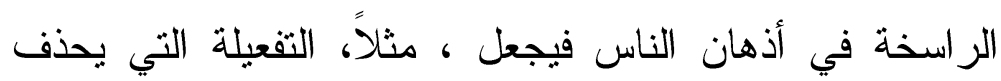

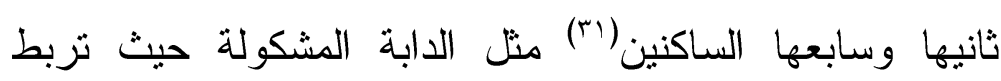
الدابة من قو ائمها الأربع ، وهي صورة تجسد التفعيلة في ذهن

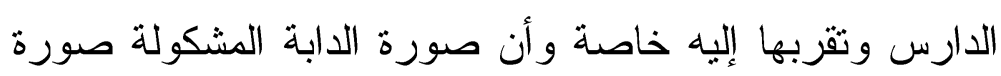
ذهنية يعرفها الدارس بسهولة ويسر .

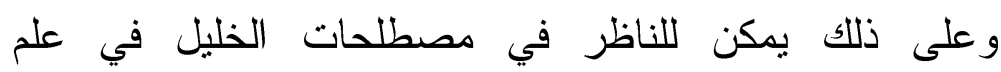

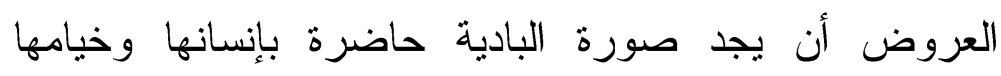

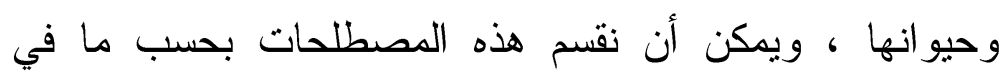

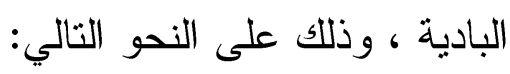

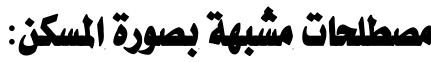

معلوم أن أهل البادية يقيمون في الخيام التي هي عبارة

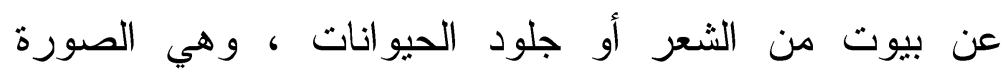

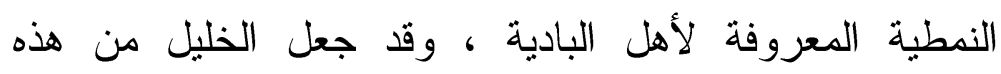

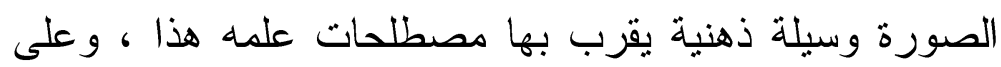

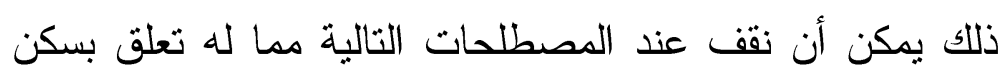

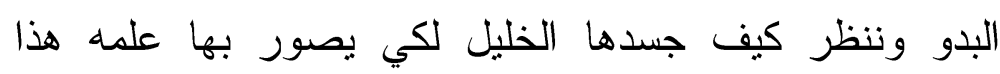

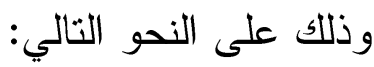
البيت: 
وبيت البدوي هو خيمته ، وعلى هذا فإن البيت من

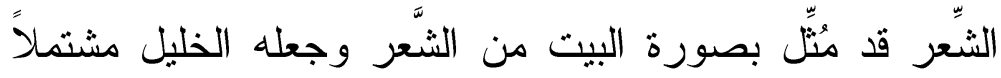
على كل ما يشتمل عليه البيت من الثعر ، وذلك ليقرب الصورة

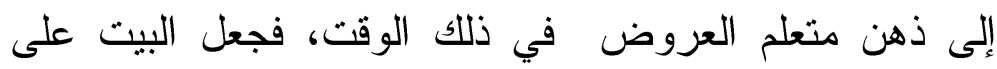

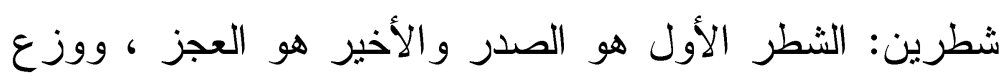

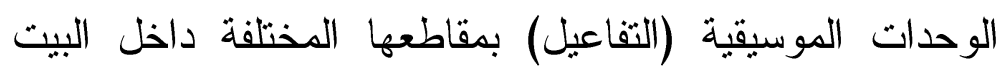
مثلما يوزع البدوي متاعه في الخيمة ، فجعل التفعيلة الأخيرة

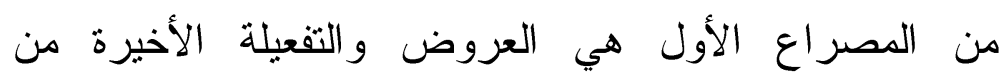

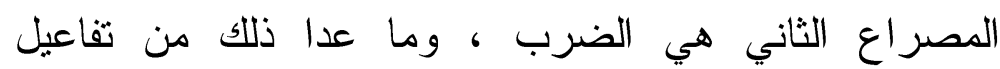

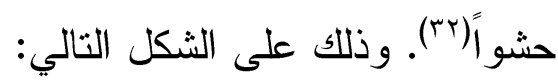

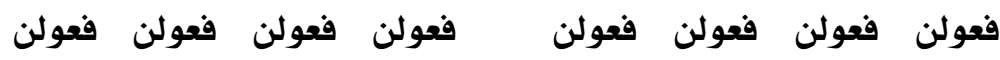

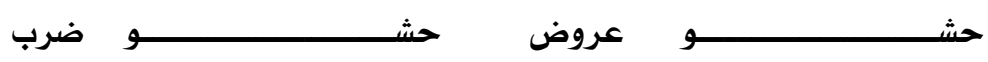
أما العروض: فهي عارضة البيت، من الشعر،

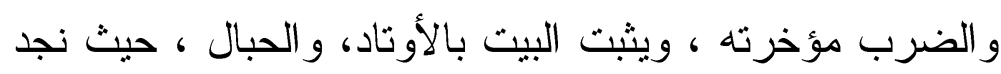

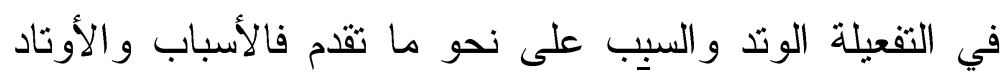

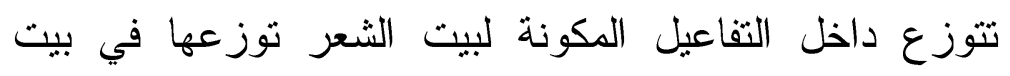

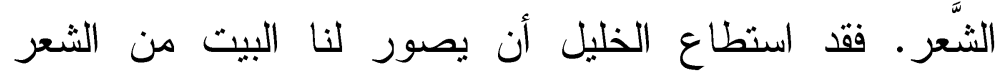

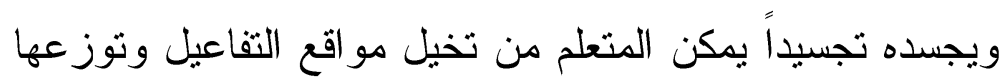

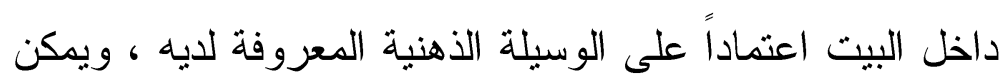
حصر المصطلحات المتعلقة بالبيت من الشعر في الآتي:

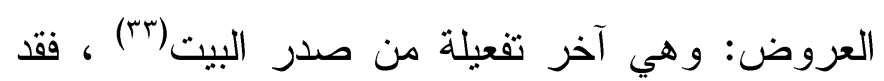

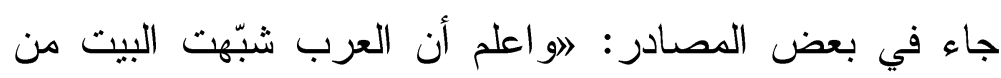

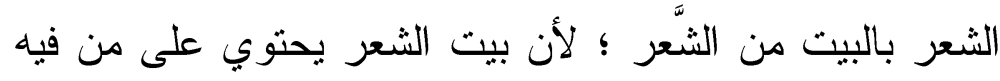

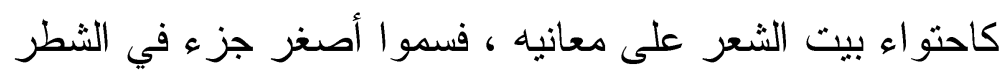


الأول من البيت عروضاً ، تشبيهاً بعارضة الخباء ، وهي الخشبة المعترضة في وسطه ؛ ولذلك سمي هذا العلم عروضاً

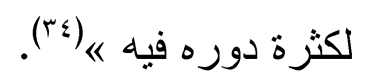

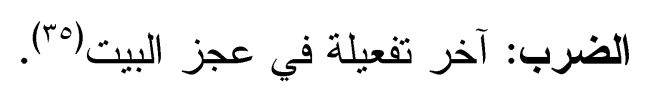

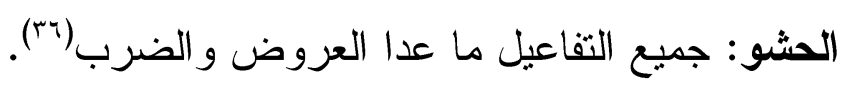

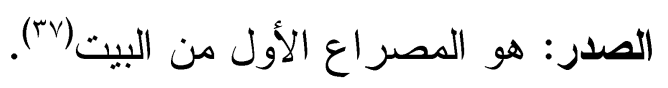

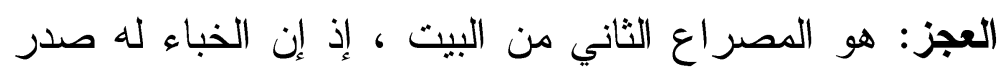

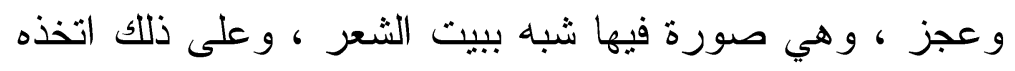

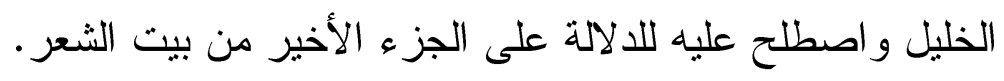

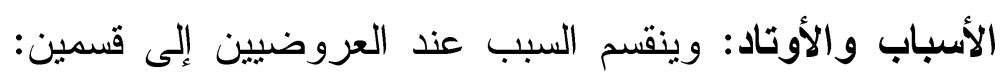

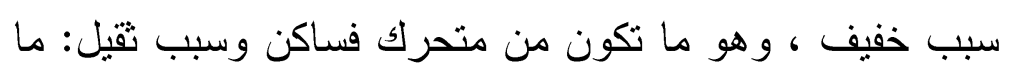

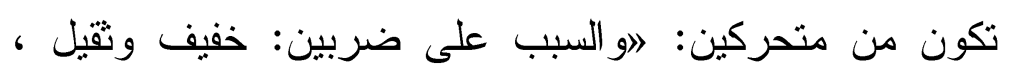

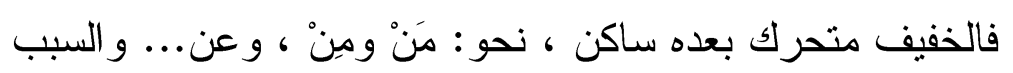

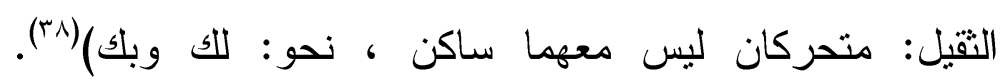

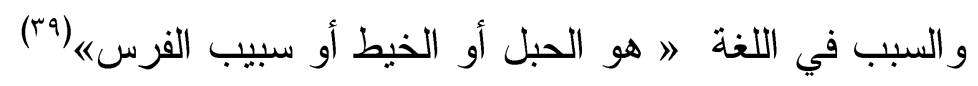

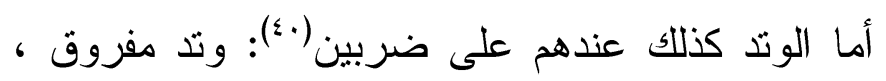

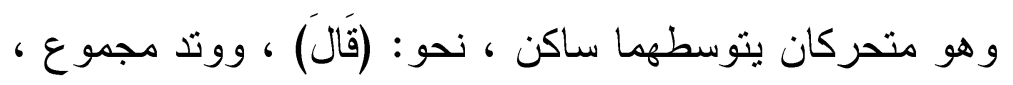

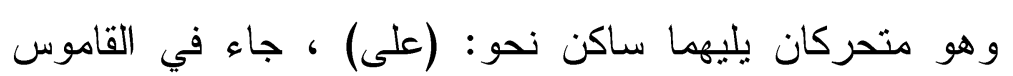

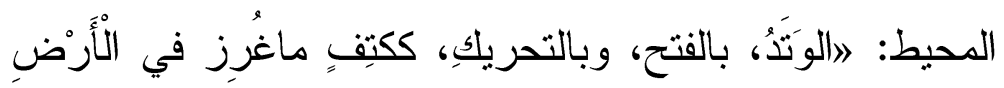

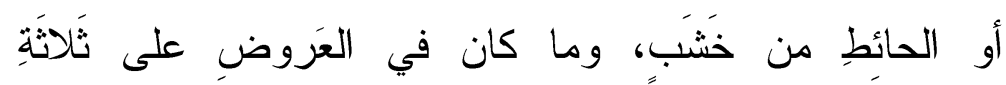

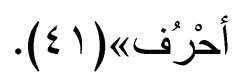

وتتكون التفاعيل من هذه المقاطع العروضية المتمنلة في

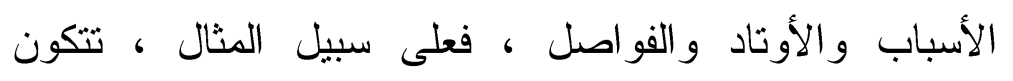
(مفاعلن) من وتد مجموع فسبيين خفيفين ، وتتكون (فعولن) 
من: وتد مجموع فسبب خفيف ، و هكذا تتكون التفاعيل من هذه الأسباب و الأوتاد و لا يخفى ما في هذه المصطلحات من تصوير

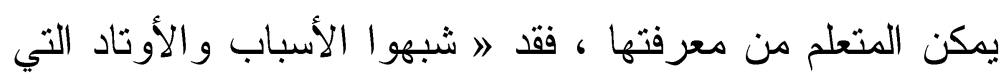

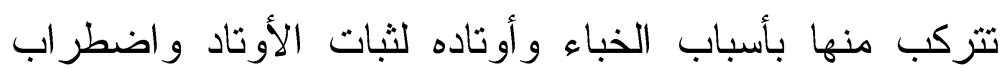

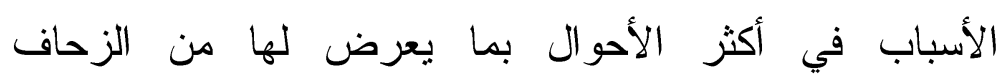

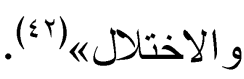

و القطع و إن لم يكن متعلقاً بصورة مباشرة بييت الشعر إلا أن وقوعه على الوتد جعل بينه وبين البيث من الثعر نسباً

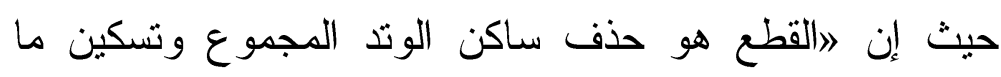

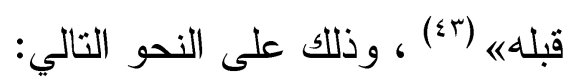

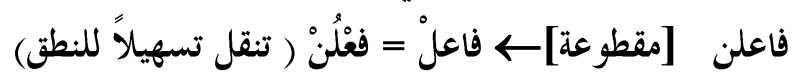

يقول الدمنهوري في توجيه التسمية : ا(سمي بذلك

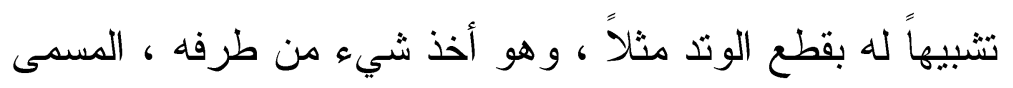

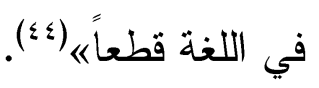

ومما يلحق بهذا التصوير والتثبيه المتعلقين بسكن

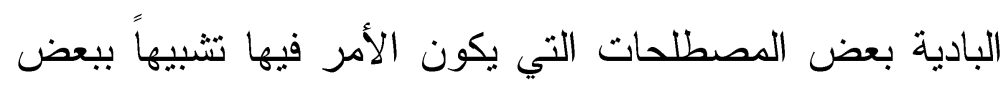

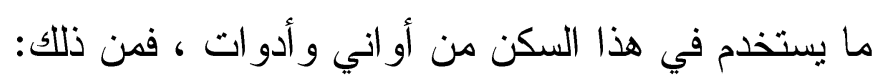

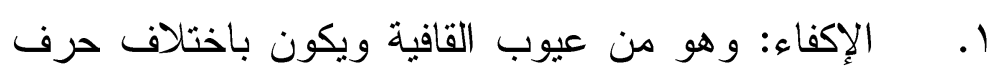

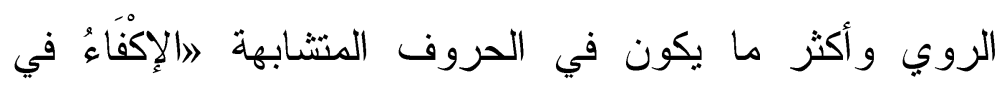

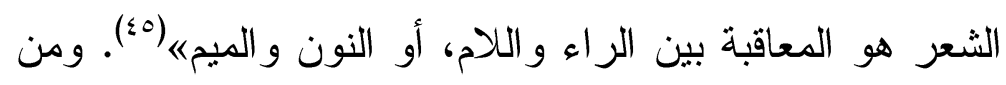

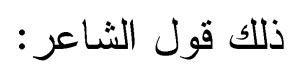

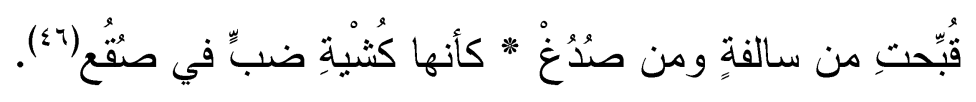




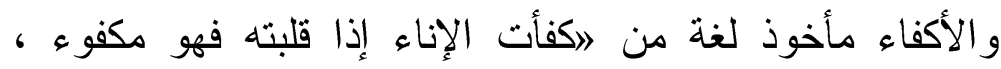

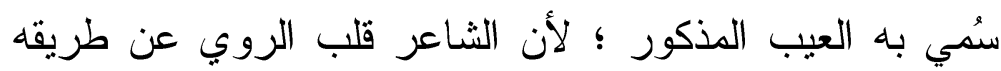
المألوفي (\&v) r. الإقواء: وهو اختلاف حركة الروي من كسر إلى ضم

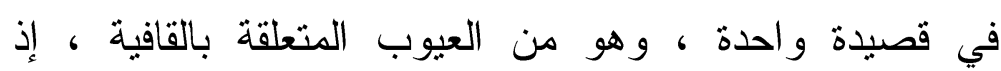

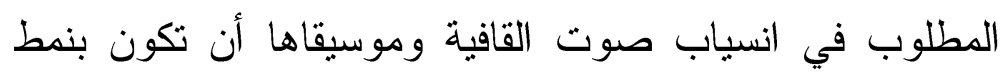

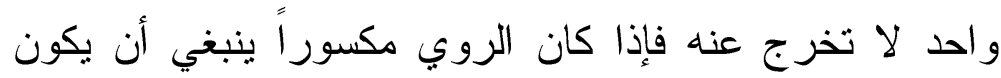

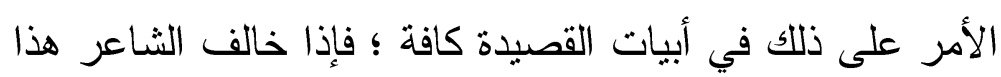

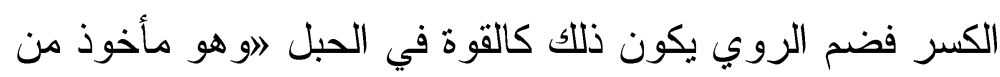
قولهم: حبل قوي بمعنى مختلف القوى بالضم ، أي: الطاقات ، كأل

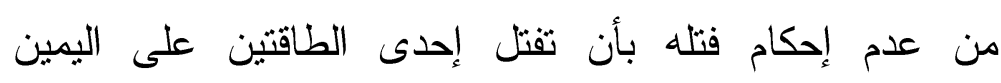

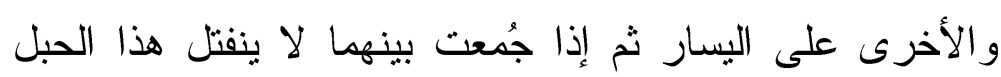

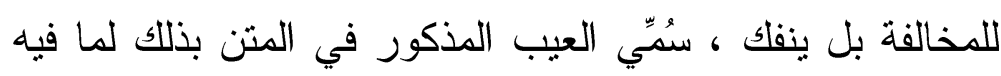

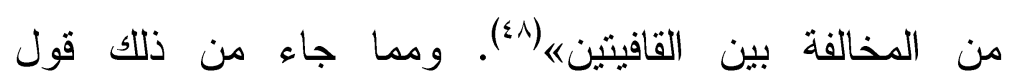

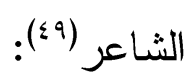

أمن آل مية رائح أم مغتدي * عجلان ذا زاد اد وغير مزودِ ليأتي قوله بعد ذلك:

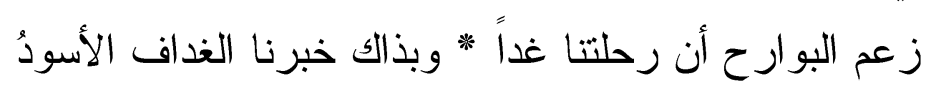

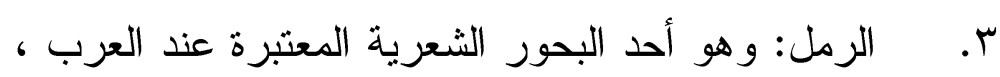

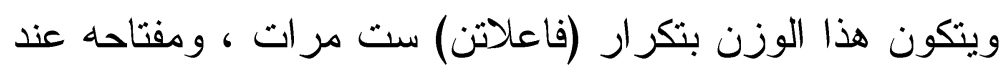
العروضيين: رَمل الأبحر يرويه الثقات فاعلاتن فاعلاتن فاعلاتن(.0.)

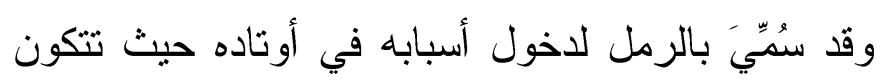

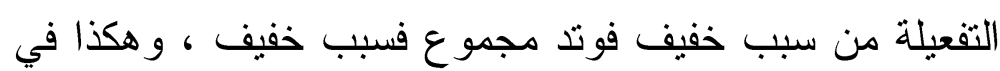


جميع التفاعيل فتكون الأسباب داخلة في الأوتاد ، وذلك يجعله

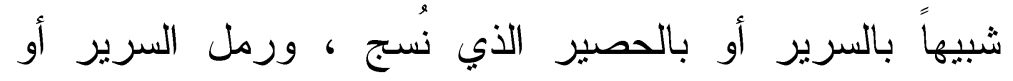

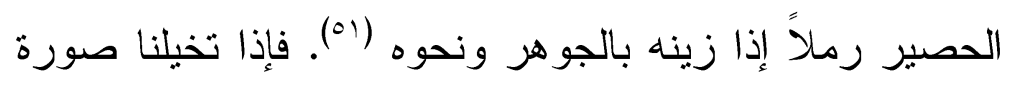

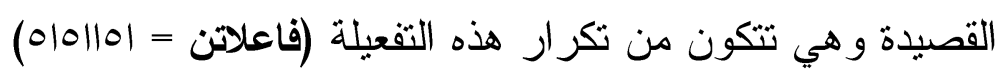

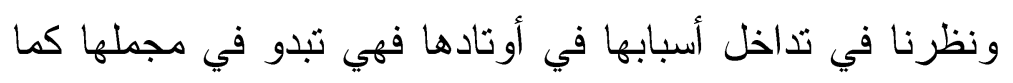
ذكر كالحصير أو السرير الذي نُسج. هكذا عقد لنا الخليل صورة ذهنية ربط فيها بين المدلول

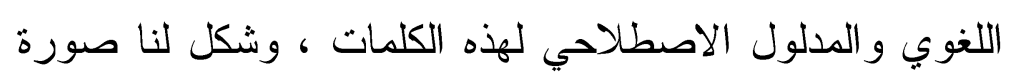
بدوية عامرة بكل ما في البادية من حياة. مصطلحات مشبهة بصورة الإنسان:

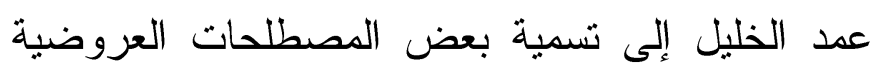
بألفاظ ذات مدلول يشبه حالة الإنسان عندما يعتريه تغيير معين،

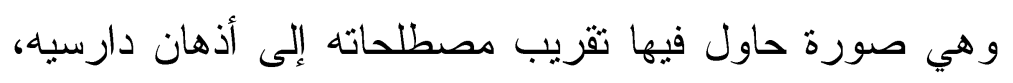
وقد وجد في التثبيه بالإنسان في مواضع معينة وسيلة ذهنية

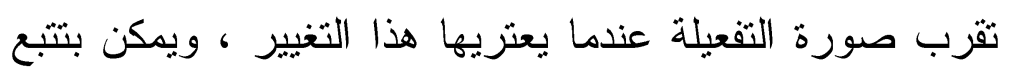
هذه المصطلحات أن نتبين ذلك ، و المصطلحات هي: بترئ الوقص:

و هو حذف الثاني المتحرك من الجزء متفاعلن، ويدخل

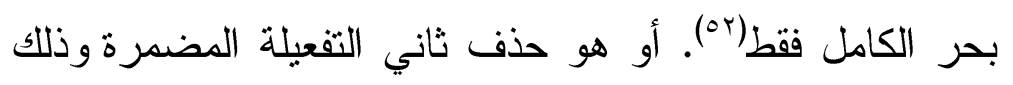
على الشكل التالي: بحلى متتفاعلن [مضمرة]

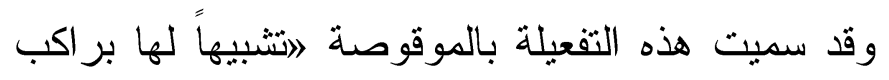

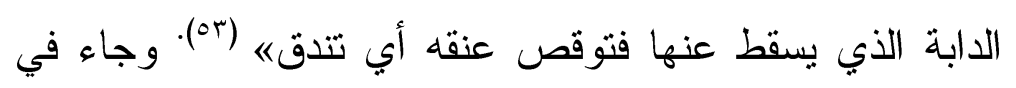

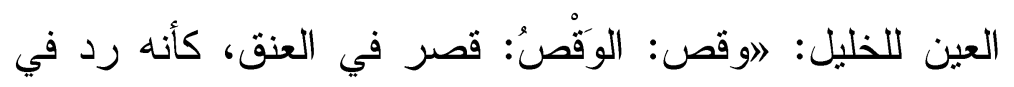

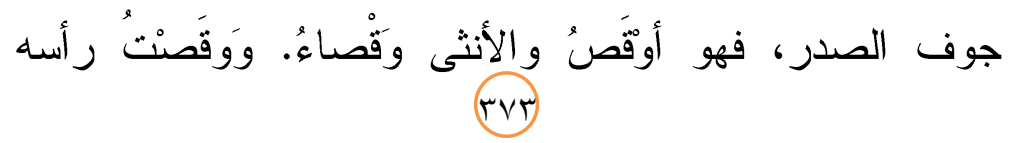


وقَصْاً: غمزته غمزاً شديداً وربما اندقت منه العنقه(\&). وقد جاء في بعض المصادر: الاووجه التسمية أن الحرف الثاني الثنائ بمنزلة عنق الحيوانه(00).

وجاء عند بعضهم الوقص كسر العنق( (1). فإذا نظرنا

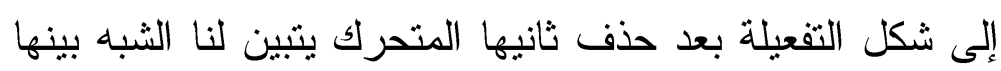

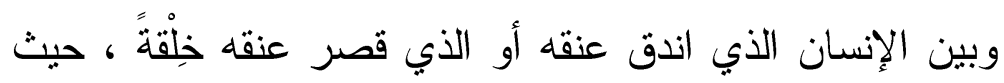
تبدو التفعيلة أقصر مما كانت عليه.

العقص وهو حذف الميم من ( مفاعيل ) فيبقى ( فاعيل)

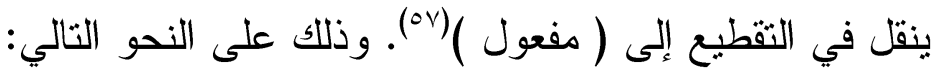
مفاعيلن [معقوصة ]ـ ـ فاعيلن وتنقل إلى: مفعولن.

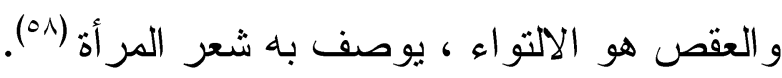
الخرم:

هو حذف أول الوتد المجموع في صدر المصراع الأول

أو الثاني (ن9)

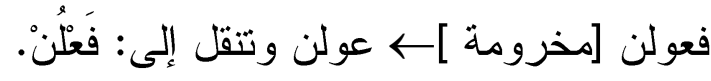

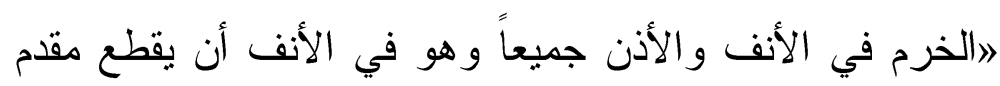

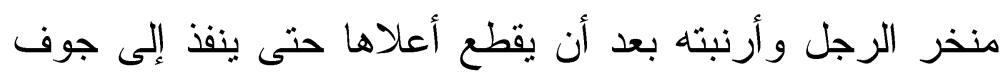

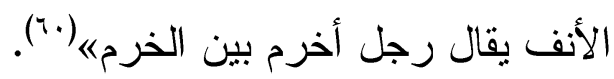
و هي صورة لا تخطئها العين عمد إليها الخليل فصور بلفر بها هذه التفعيلة التي تتقص من أولها بحذف أول حرف فيها ، فنتبدو كالرجل الذي قطع أعلى أنفه ، وتأتي على منو ال هذا المصطلح

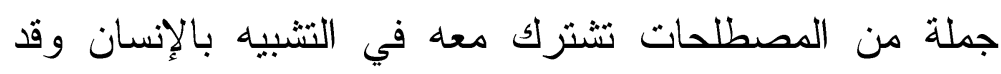
قطع طرف من أطر افه ، ومن هذه المصطلحات: 
أ/ الصلم: إسقاط وتد مفعولات ، وجاء من صلمه قطعه

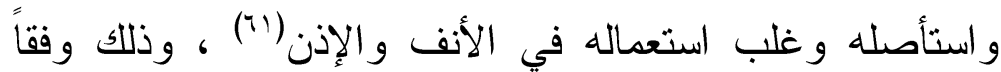

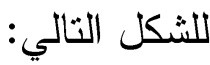

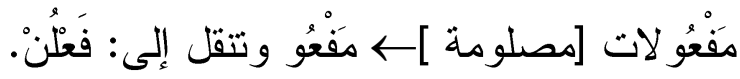

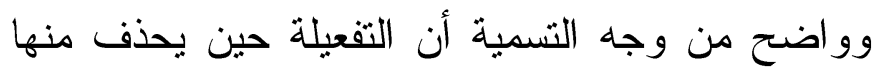
الوتد المفروق من آخرها تصير كالشيء المستأصل ، وتشبيه التفعيلة في ذلك بالإنسان الذي استأصلت أنفه أو أذهنه مما يمكن الهن الهن

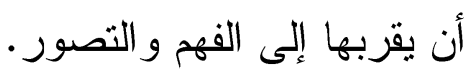

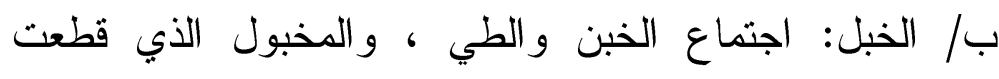

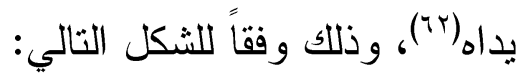

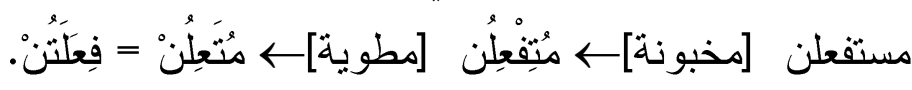
فنقص حروف التفعيلة جعلها نثبه الإنسان الذي قطعت جـ/ الثرم: هو خرم يدخل على فعولن المقبوضة. و الأثرم الذي

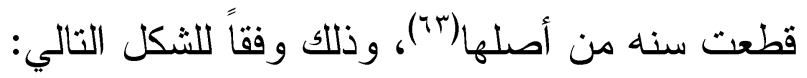

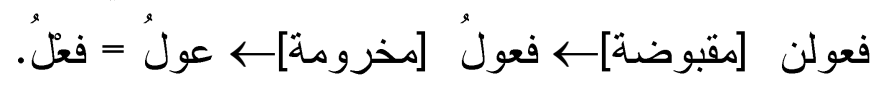

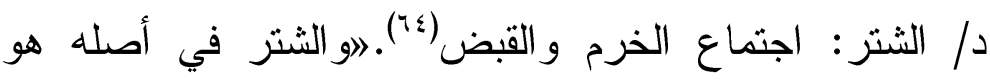
القطع و الثق ويكون للثفة السفلى وجفن العينه(10) ، وذلك وفئاً

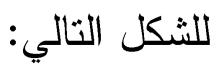
مفاعيلن [ [خرم]ـ ثاعيلن [ [مقبوضة] ومن صور الإنسان ما يكون عليه في بعض حركته ،

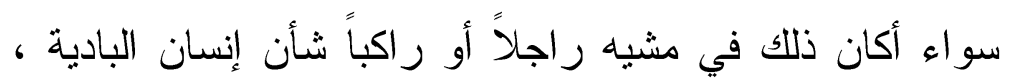

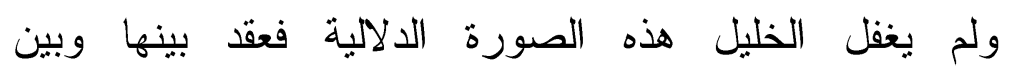
مصطلحاته علاقة ، ومن ذلك ما يلي من مصطلحات: 
وهو حرف دد ألف أو واو أو باء ، يكون قبل الروي

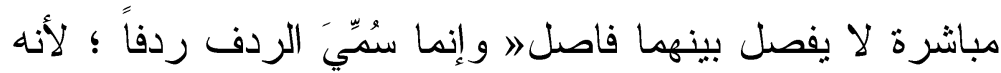

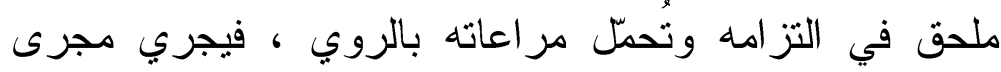

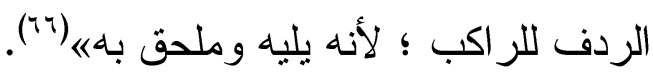
الإيطاء: الردا:

و الإيطاء من عيوب القافية ، إذ الأصل أن ينوع الثاعر

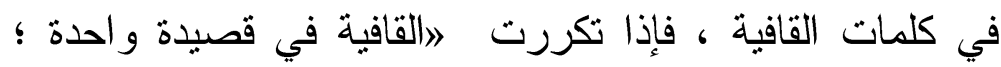
بمعنى واحد كالرجل و الرجل ، فإن كان لمعنيين لم يكن إيطاء نحو: رجل نكرة ، و الرجل معرفة ، وذهب بمعنى الفعل ، بلرجل

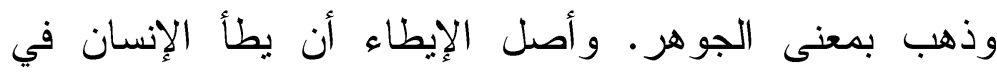

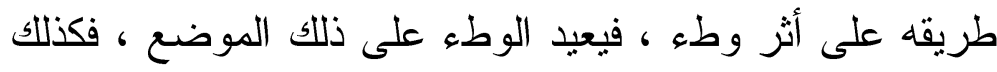
إعادة القافية و هو من هذاهي (TV) فقد جعل تكرار كلمة القافية بمثابة أن يعيد الإنسان وطء أثنا

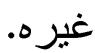
وكذللك جعل الخليل مما يعتري الإنسان من مرض

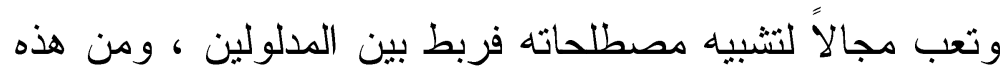

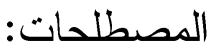
أ/ العلة:

و هي اتغيير بالزيادة والنقصان يدخل على الأسباب والأوتاد في العروض والضرب ، ويلتزم في جميع أبيات

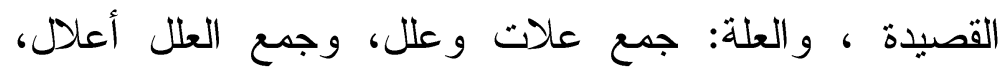
و العلة: المرض والخلل ، ولعل وجه التسمية أن في العلة إخلالاً بالتفعيلةها ("1). 


\section{ب/ الرسى:}

و الرس من حركات القافية ، وهو 》الفتحة قبل ألف الف الفئان

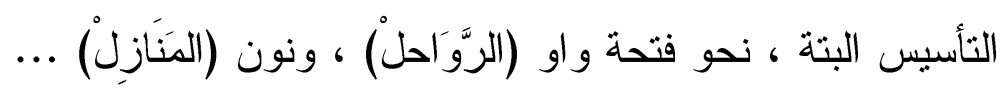

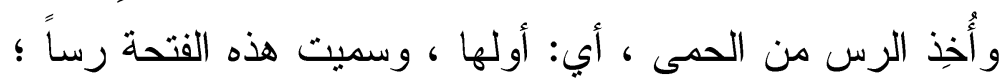

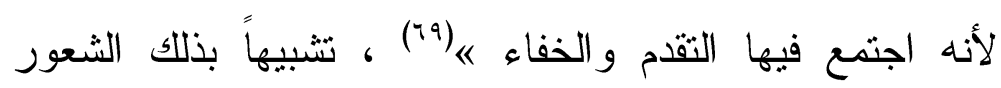
الخفي الذي يحسه الإنسان قبل أن تتمكن الحمى من جسده.

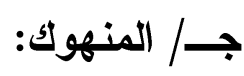

وهو البيت الذي ذهب ثلثاه وبقي ثلثثه ، ويقع في بحر الرجز والمنسرح ، او إنما سُِّّي بذلك ؛ لأنا حذفنا تلثيه فنهكناه

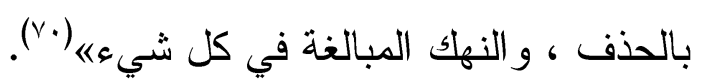
هكذا وظف الخليل صورة الإنسان ، فجعل من هذه فئه الصورة في مختلف أثكالها وسيلة يوضح بها ما يعتري التفعيلة

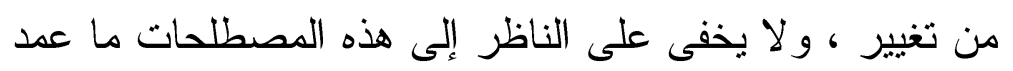

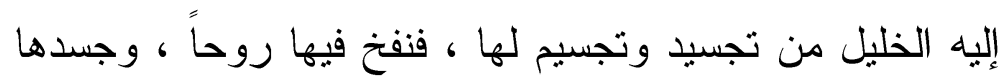

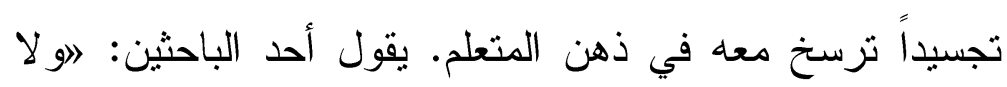

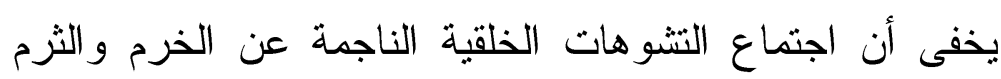

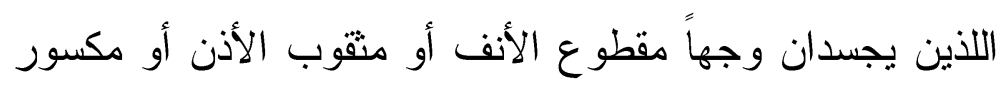

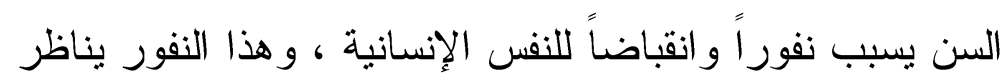
نفور العروضيين من اجتماع الخرم والتلم في التفعيلة (فعولن) (v) 


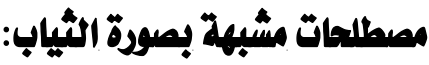

الثياب من الأثياء المألوفة لاى الناس ، ولهابان عندهم

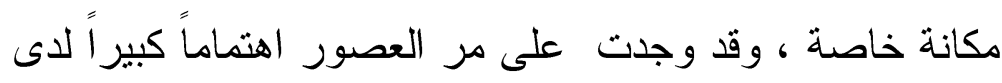

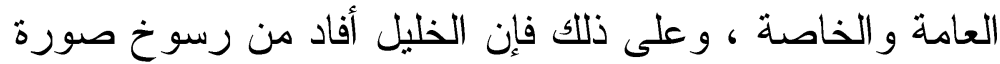
الثوب في ذهن الناس ، فجعل مما يحدثه فيها الناس من تذييل وكف وطي صورة يشبه بها ما بعتري التفاعيل من تغييرات بحدثها الثعراء ، وجعل التفعيلة في بعض صورها كالثوب

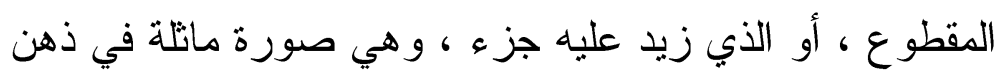

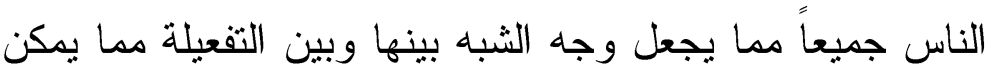
أن يستظهره الدارس ، ومن هذه المصطلحات:

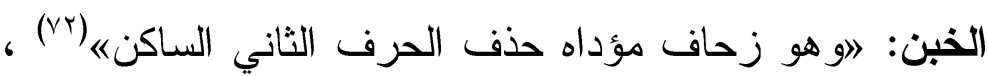

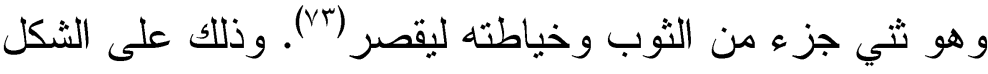

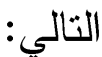

\section{فاعلن [مخبونة] ـ فَعَلُنْ}

وواضح من خلال الثكل أعلاه ، الثقليص الذي حدث

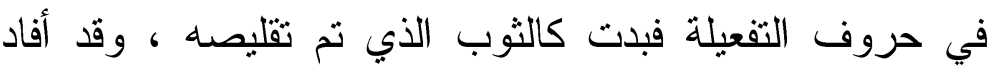
الخليل من هذه الصورة في تقريب فكرة حذف الثاني الساكن وما تكون عليه التفعيلة حين يحذف ثانيها. وتلحق بهذه الصورة مصطلحات لا تخرج عن كونها نوع من التقليص يكون التغيير فيها بحذف حرف من حروف

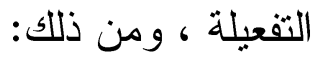
أ/ الكف: وهو إسقاط السابع الساكن من التفعيلة(Y) فتكون كالثوب تعهده صاحبه بالكف ليقصر، وذللك على كالمثال

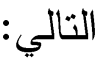




\section{مفاعيلن [محذوفة] ـ مفاعيلُ}

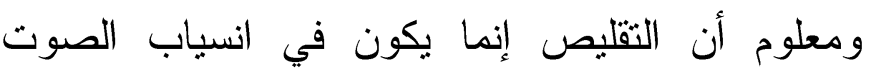

بالتفعيلة حيث يؤدي حذف الحرف الثاني الساكن إلى تقليص

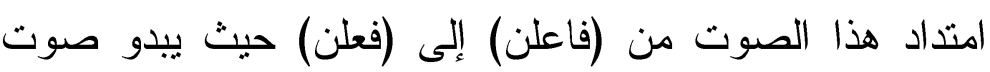

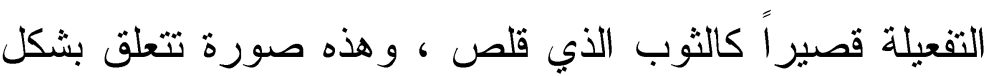
التفعيلة الخطي ويكون القِصرَ حينا التلفظ بصوتي الفعلي أيضاً.

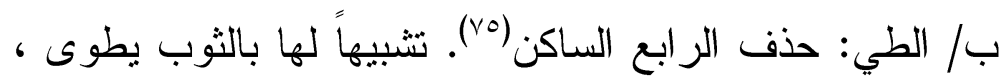

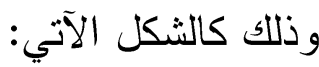

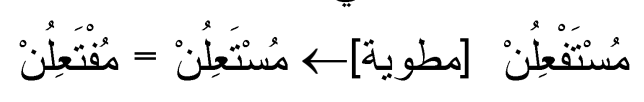

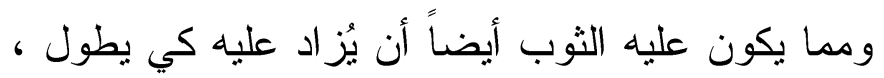

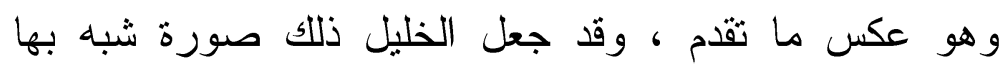
تفاعيله حين تعتريها الزيادة ، وخلق علاقة بين التفعيلة وبين

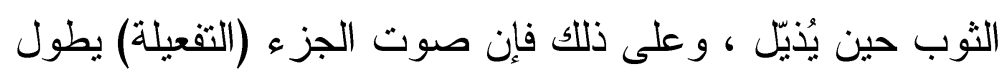

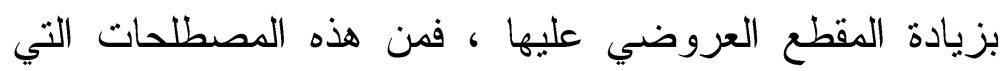

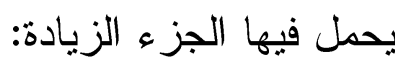
أ / القذييل:

وهو زيادة حرف ساكن على الوتد المجموع آخر

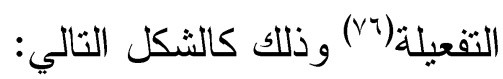

متفاعلن [ذالة] ـ متفاعلانْ

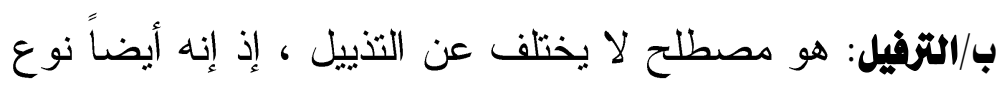
من الزيادة ولكن بعدد أكثر من الحروف فلتبدو معه التفعيلة كالثوب الذي يرفل فيه صاحبه لفرط طوله ، و الترفيل يكون

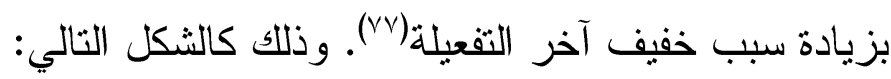
متفاعلن [مرفلة] ـ متفاعلاتن. 
جـ/ التسبيغ وذلك بزيادة حرف ساكن في آخر التفعيلة ، فتبدو كالثوب السابغ ، وذللك كالثكل التالي: فاعلاتن [مسبَّغة] ـ فاعليَّانْ = فاعلاتانْ

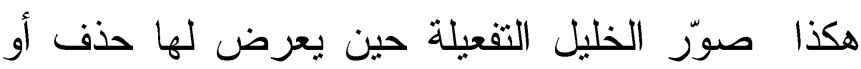
زيادة في بعض حروفها، فأخذ من بيئته صورة شبه بها التفعيلة

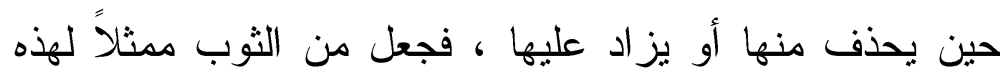

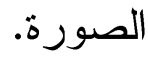

\section{مصطلحات مشبهة بصورة الحيوان:}

وجد الحيوان حظه أيضاً من التشبيه و التمثيل حيث شبه

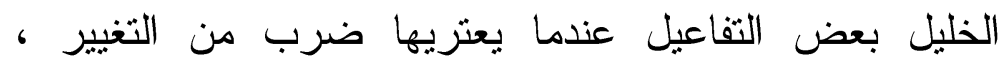

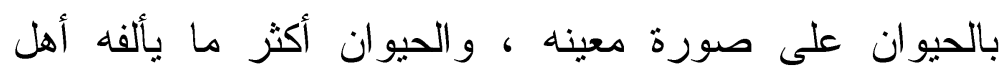

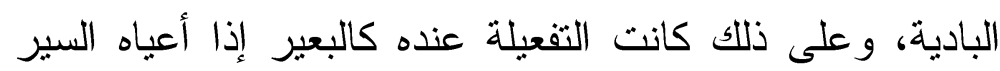

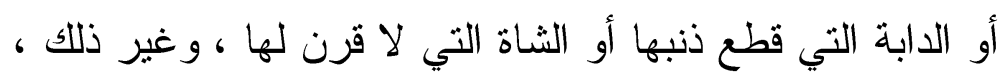

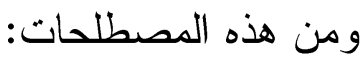

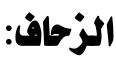

اتغيير بالحذف أو التسكين ، يدخل على الحرف الثاني من

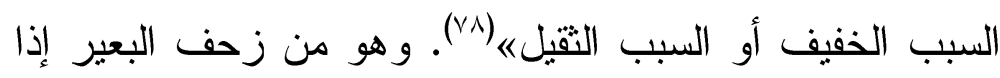

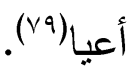

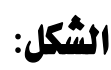

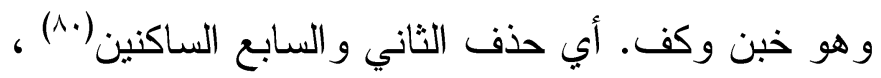

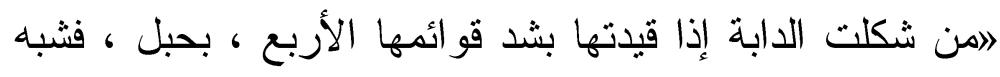

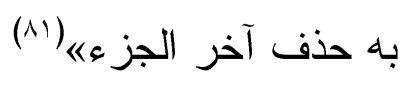

فاعلاتن [مشكولة] ـ فعلاتن [مكفوفة] ك فعلاتُ.

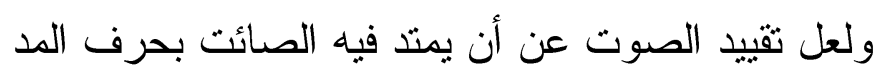
الثاني من (فاعلاتن)، ثم حذف السابع وهو النون ، و النون هي 
محل الوقف فينقطع الصوت قبلها ويوقف على التاء (فاعلات) ، حيث يبدو الصوت مقيداً على نحو يشبه معه ما ذكر من شكل فله

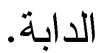

هو زحاف مؤداه تسكين الخامس المتحرك ، وذلك على

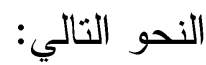
مفاعلنن [معصوبة]

ووجه التسمية من عصب الثيء يعصبه عصباً أي:

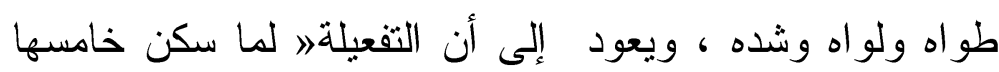

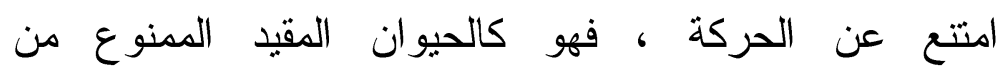

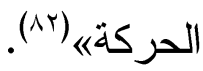

الأعضب هو الذي ذهب أحد قرنبه(^م) ، و العضب

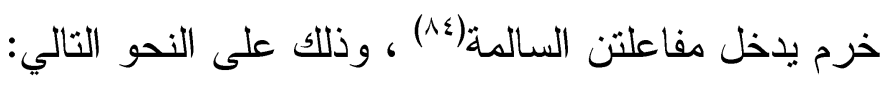

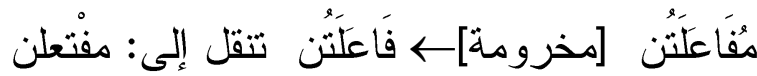
البتز:

اجتماع الحذف والقطع (^) ) و والبزر يكون بقطع الذنب

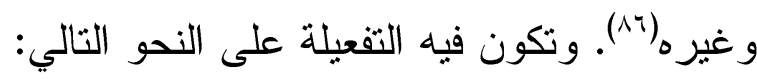

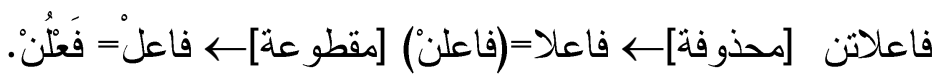

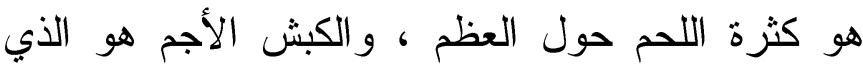

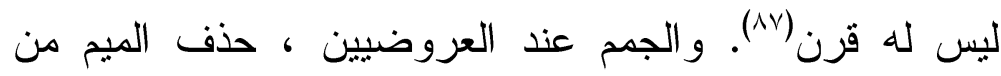

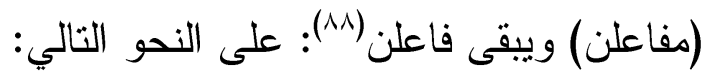

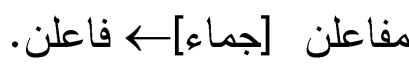


زيادة ما دون خمسة أحرف في أول الثطر غالباً ، وقد

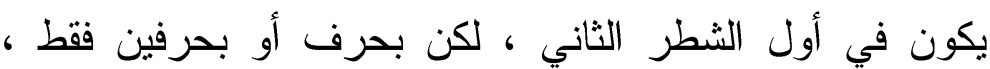

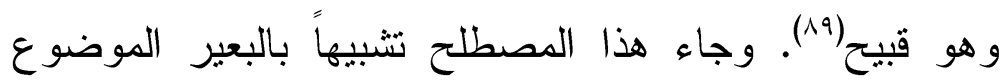

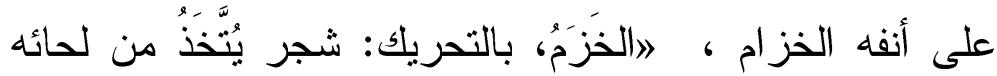

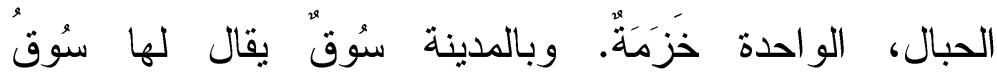

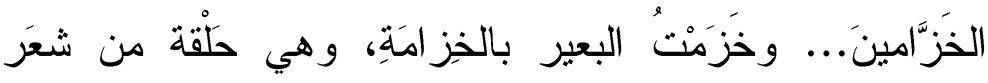

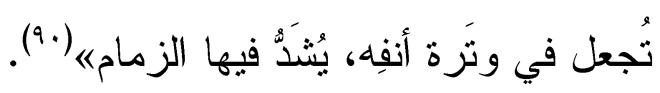

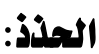

هو حذف الوتد المجموع من آخر التفعيلة(19)، وذلك

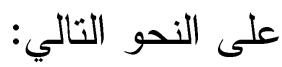

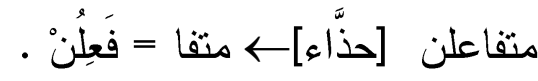
يقول الدنهوري: اوهو لغة القطع ، ويطلق على قصر

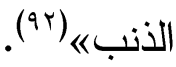

وعلى ذلك فإن التفعيلة عندما تحذ تصير شبيهة بالدابة

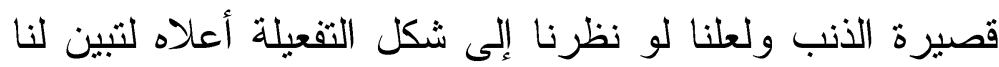
ذلك ، فمتفاعلن تصير فعلن ، وتبدو متل تثبيههم لها بالدابة. وتجد صورة الحيوان في مشيه وقيامه من حيث

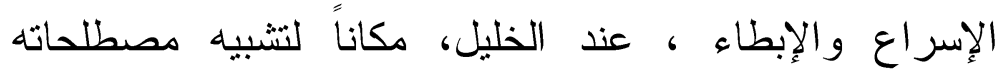

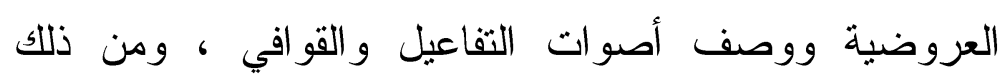

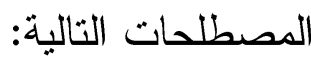
الرجز: جاء في اللسان الرَّجَزُ : الداء يصيب الإبل في أَعجازها.

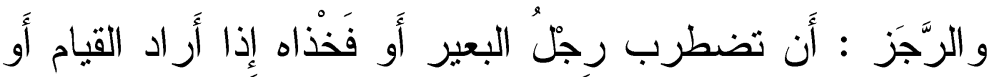

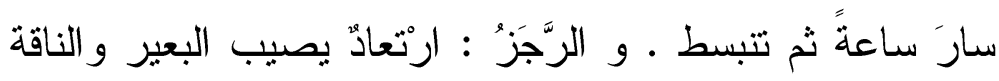

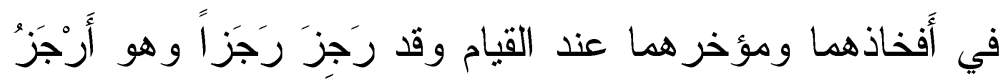




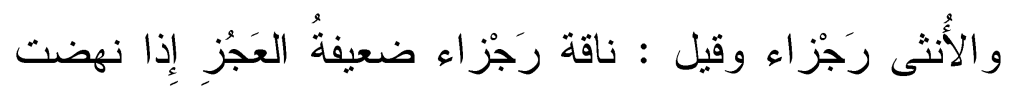

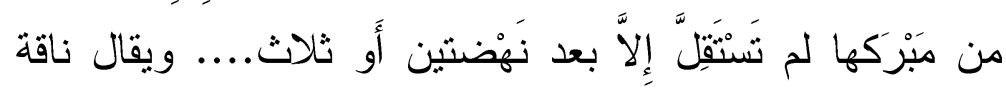

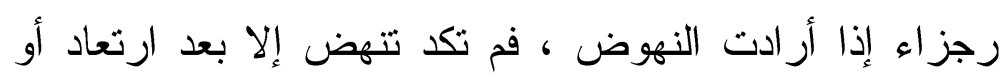
ارتعاش شديد. ومنه سمي الرجز من الشعر لتقارب أجزائه،

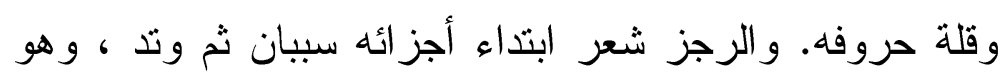

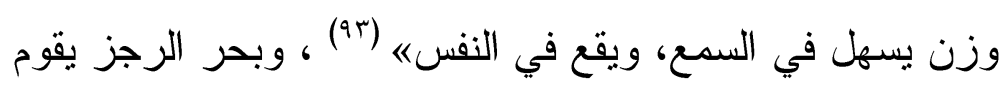

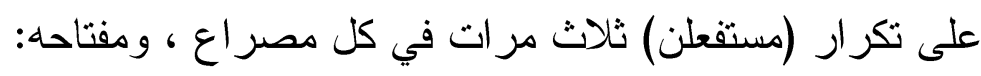

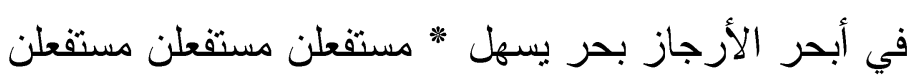

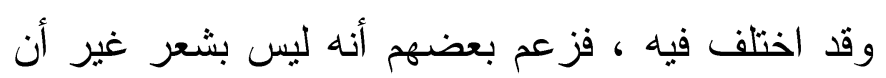
الخليل ذكر أنه شعر صحيح(ع9) . ويبدو أن تقدم السبيين الخففين وتأخر الوتد المفروق ، جعل التفعيلة تشبه الناقة ضعيفة

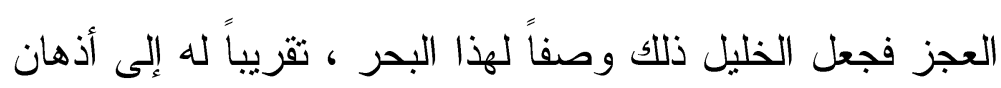
متعلمي عروضه.

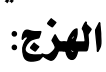

الهزج نوع من الغناء الخفيف الذي يرقص عليه ويُمُنَى

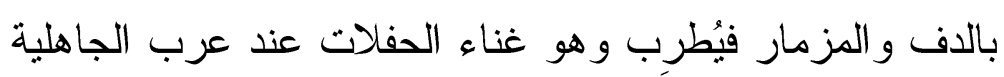

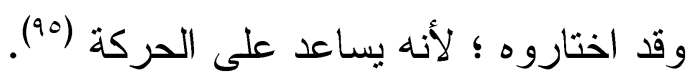
أصل وزن هذا البحر كما يلي:

مفاعيلن مفاعيلن مفاعيلن * مفاعيلن مفاعيلن مفاعيلن

مفناحها:

على الأهز اج تسهيل * مفاعيلن مفاعيلن

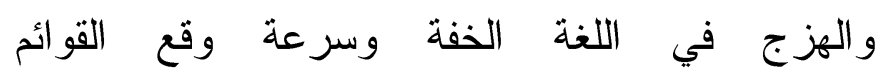
ووضعها(9י). ولعل تقارب أجز اء هذا الوزن جعل له هذه الخفة، وفئ 
فأشبه بذلك في أجزائه وسرعة الانتقال منها لتقاربها ، كتقارب قو ائم الفرس في سيره.

المتكاوس:

و هذا المصطلح لقب يتعلق بالقافية ، حيث وجد في

الصورة غير الطبيعية لهشي الناقة ، إذا مشت على ثلاث قو ائم،

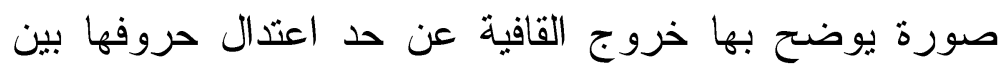

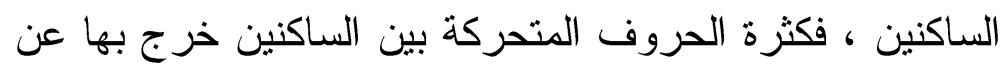

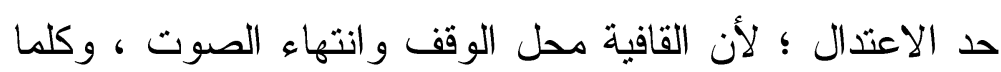

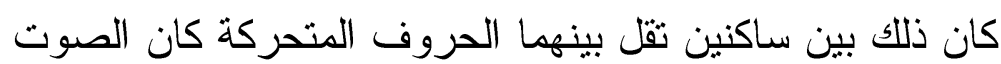

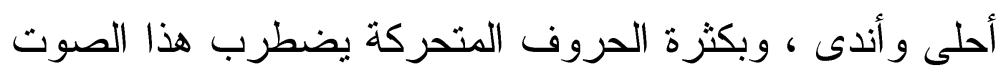

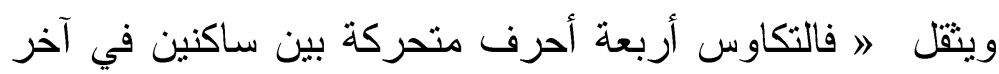
البيت ، نحو قوله:

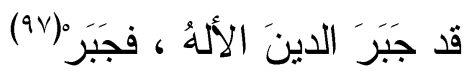
و إنما سمي متكاوساً للاضطر اب ومخالفة المعتاد. و ومنه:

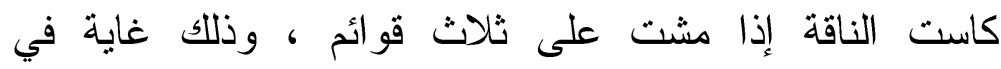

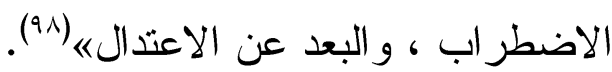
هكذا جاءت مصطلحات الخليل العروضية متخذة من

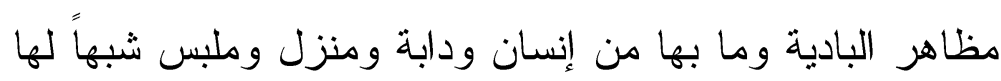

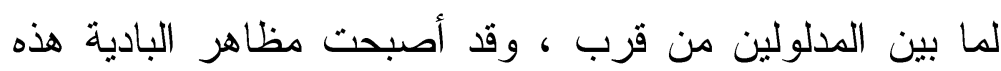

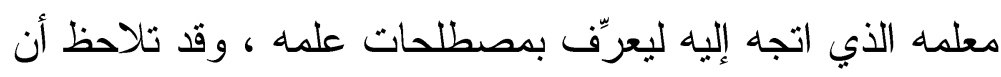
هذه المصطلحات رغم تقادم العهد عليها قد ظلت على حالها و لا يكاد أحد يجسر على تغيير ها أو تعديلات سوى بعض الدهات الدعوات

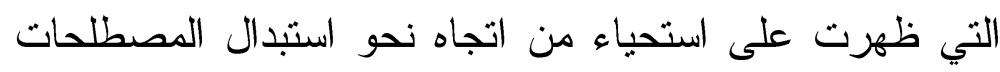
بالإيقاع و غير ذلك مما يمس جوهر ما بناه الخليل وشاده. 
بالنظر إلى ما ثقام رأينا كيف أن الخليل ومن أتى بعده

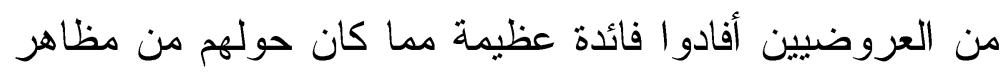
البادية ، فجعلوا مصطلحاتهم العروضية ذات مدلول يتعلق بما في هذه البيئة من إنسان ومسكن وملبس وحيوان ، و وعلى ذلك الك لئل يمكن أن نخلص إلى النتائج التالية:

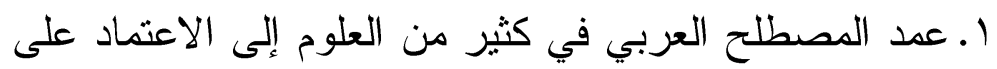
البيئة والمجتمع فعقد العلماء مصطلحات علومهم وربطوا بينها وبين البيئة الاجتماعية و الثقافية التي عاشو الفئه فئهاه

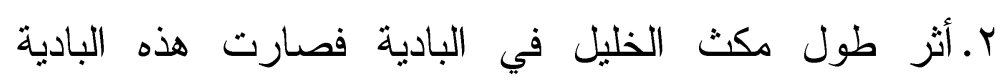
بمكوناتها جزء أصبلاً من مصطلحات علمه هذا. r.مقدرة الخليل العقلية على الابتكار واتجاهه نحو نحو التعليم ومعرفته بالبيئة البدوية من حوله جعلته يعمد إلى الإفادة من هذه الإنها البيئة فيجسد التفاعيل في صورة الإنسان أو الحيوان على هيئة

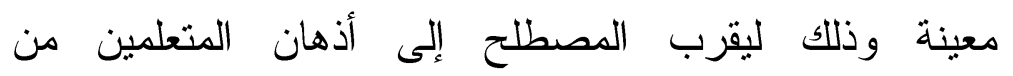
معاصريه. ع. اتخذ الخليل من مظاهر البادية الساكنة و المتحركة صورة اعتمد عليها وجعلها وسيلة تعليمية يوضح بها علمه هذا ، فعقد

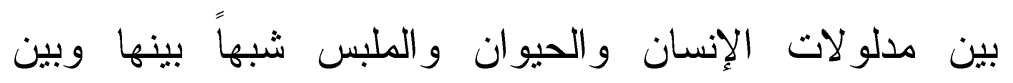
مصطلحاته العروضية المختلفة. ه.لم يخرج العلماء الذين جاءوا بعد الخليل عن هذه الذهاء

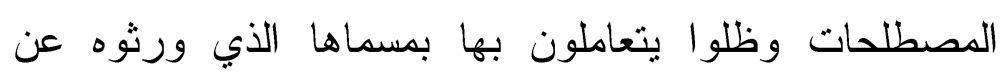
الخليل و لا يز ال مصطلح الخليل سائداً إلى يومنا هذا. 


\section{أولاً: المصادر والمراجع:}

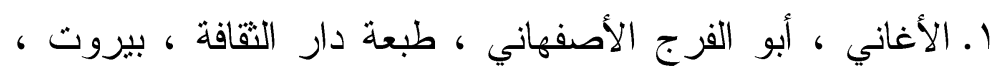

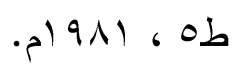

r. إنباه الرواة على أنباه النحاة ، علي بن يوسف القفطي ، تحقيق ،

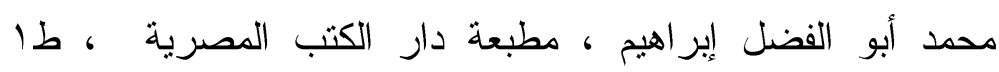
م) 90 .

r. تاريخ الأدب العربي في العصر الجاهلي ، شوقي ضيف ، دار

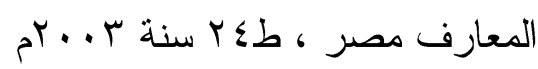

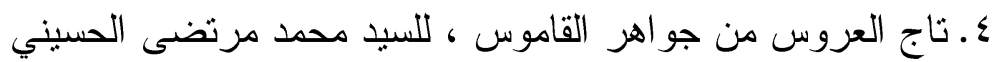

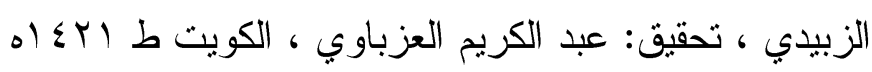

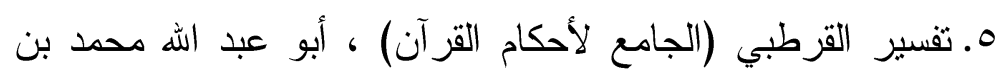

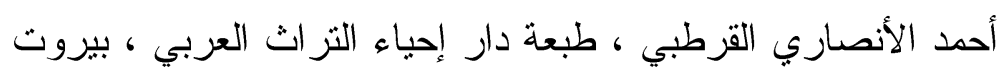

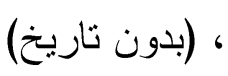

4. تهذيب اللغة ، محمد بن أحمد الأزهري ، تحقيق عبد السلام

$$
\text { هارون. ط/ الدار المصرية (بدون ثاريخ). }
$$

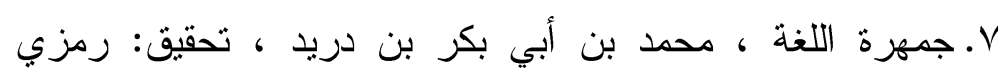

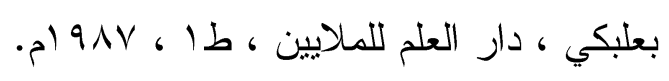

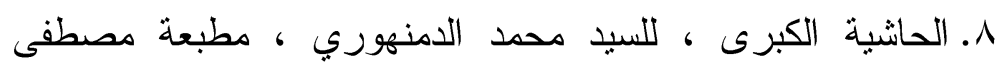

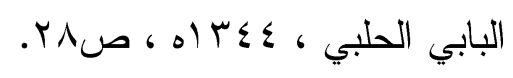

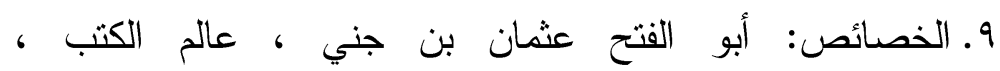
بيروت(بدون ناريخ) تحقيق: محمد علي النجار .

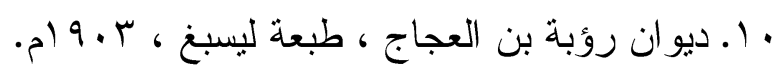

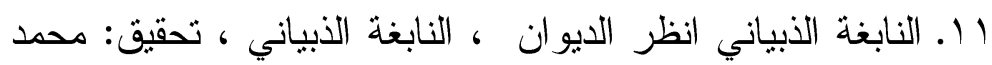

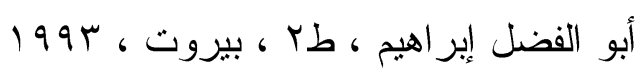

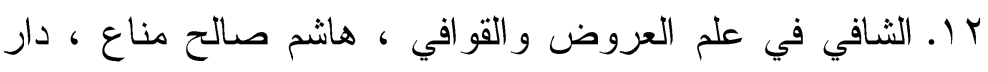

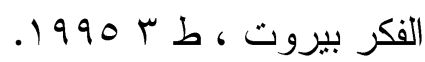


با ا. الصاحبي في فقه اللغة ، أحمد بن فارس ، تحقيق السيد أحمد الصقز مطبعة الحلبي ، 9 ام ام.

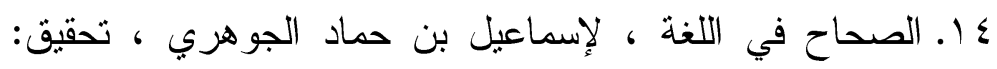

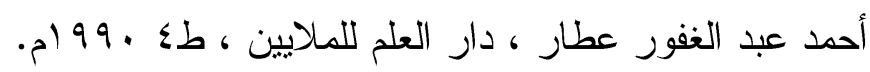

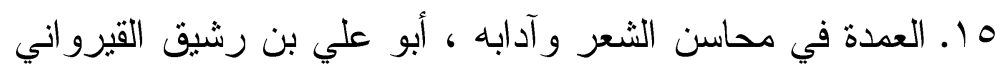

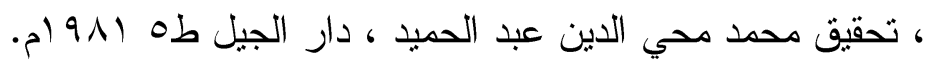

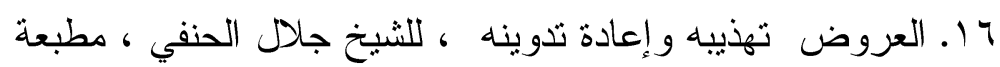

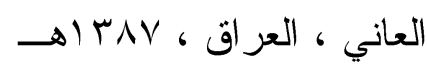

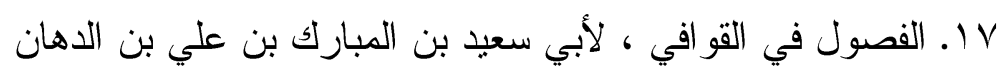

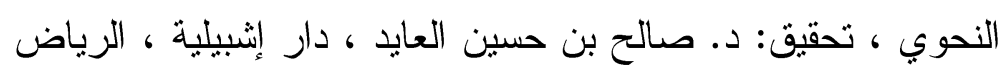

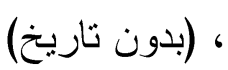

11. القاموس المحيط ، محمد بن يعقوب الفيروزآبادي ، مطبعة مؤسسة الحلبي (بدن تاريخ).

9 1. القسطاس في علم العروض ، جار الهار اله الزمخشري ، تحقيق:

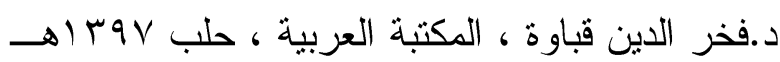

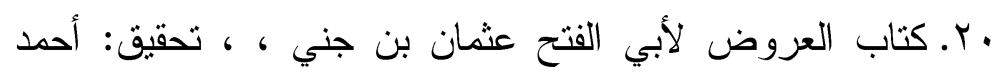

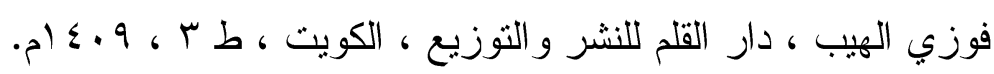

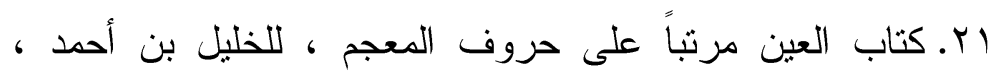

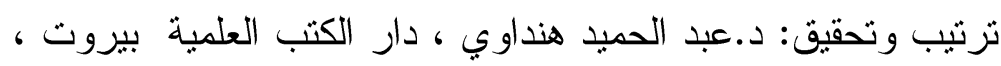
.0) $\leqslant$ r r r. لسان العرب ، محمد بن مكرم بن منظور ، دار الفكر ، بيروت

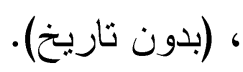

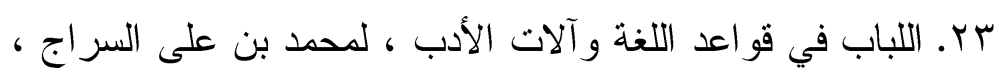

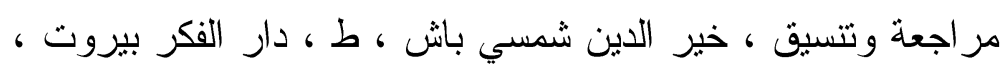
(بدون تاريخ) (برن) 
؟ Y. المزهر في علوم اللغة وأنواعها ، ، لعبد الرحمن جلال الدين

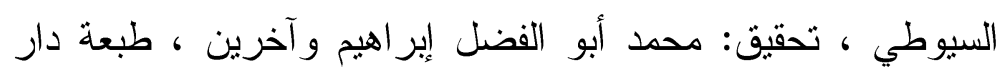

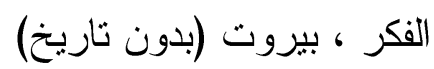

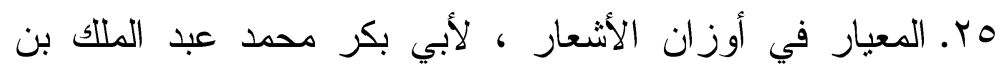

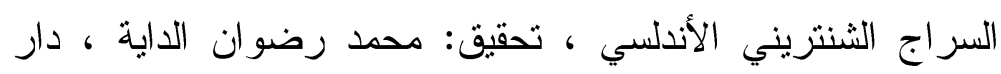

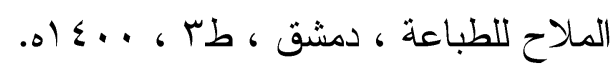

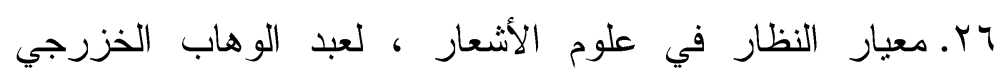

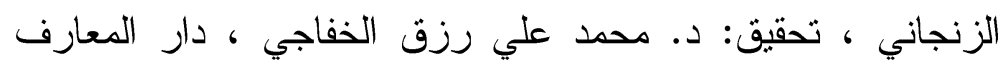

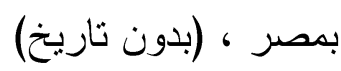

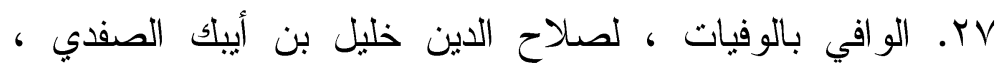

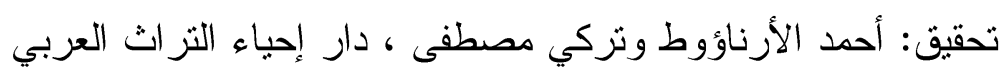

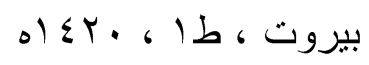

د r. الوافي في العروض و القوافي ، للخطبب التبريزي ، نحقيق:

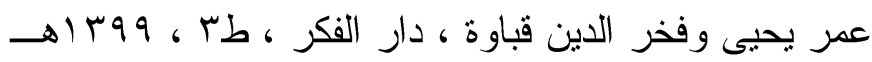
ثانياً الدوريات:

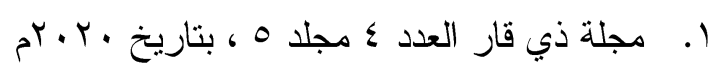

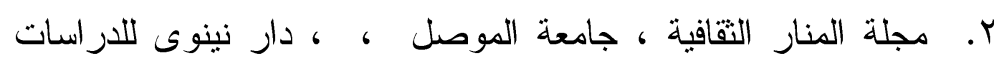

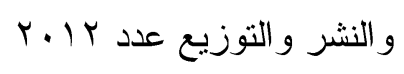




\section{هوامش البحث}

(') الأغاني ، أبو الفرج الأصفهاني ، طبعة دار التقافة ، بيروت ، طه ،

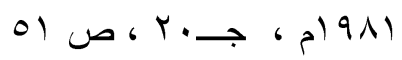

(r) العمدة في محاسن الثعر وآدابه ، أبو علي بن رشيق القيرواني ،

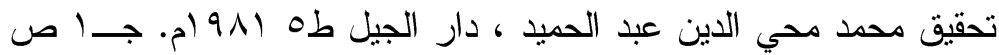

(") روي أن الحطيئة نزل ببني أنف الناقة ، وكانوا يتحرجون من هذا

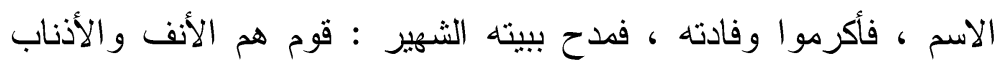

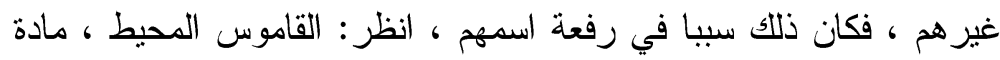
أنف

تفسير القرطبي (الجامع لأحكام القرآن) ، أبو عبد الله محمد بن أحمد

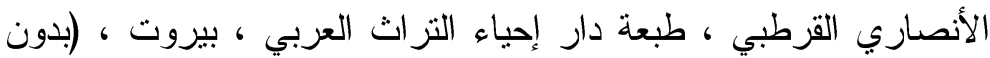

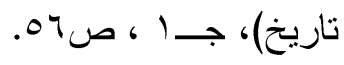

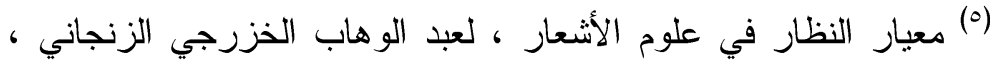

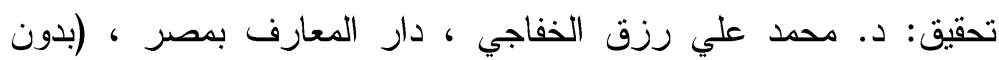

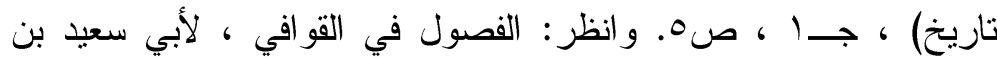

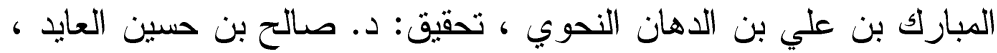

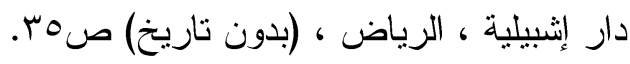

الخصائص ، لأبي الفتح عثمان بن جني ، عالم الكتب ، بيروت(بدون

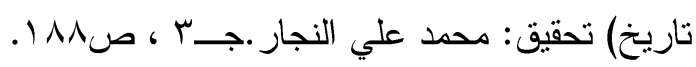

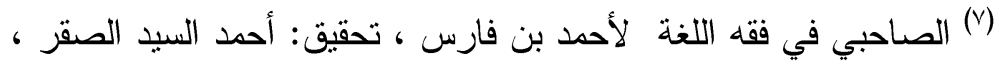

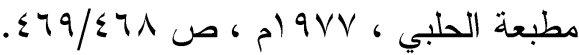

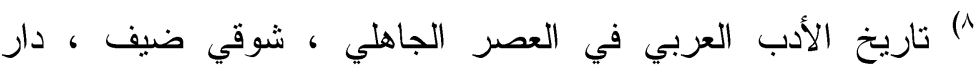

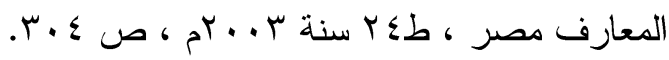


(9) على الرغم من اختلاف العلماء حول نسبة العين إلى الخليل بن أحمد

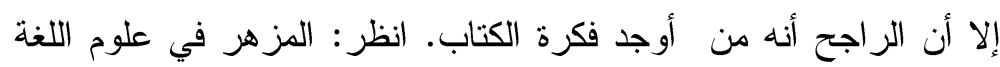

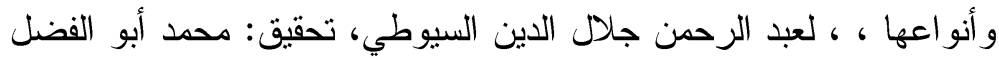

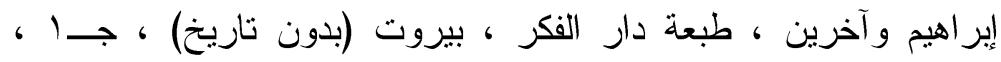

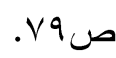

(·) الو افي بالوفيات ، لصدلاح الدين خليل بن أيبك الصفدي ، تحقيق: أحمد

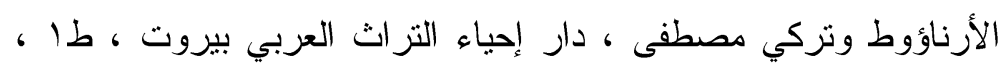

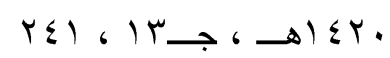

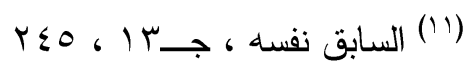

(r') الثافي بعلم العروض و القو افي ، لهاشم مناع ، ص rا

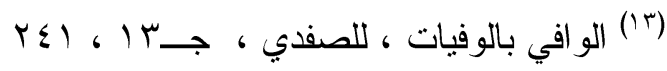

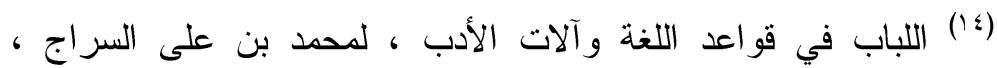

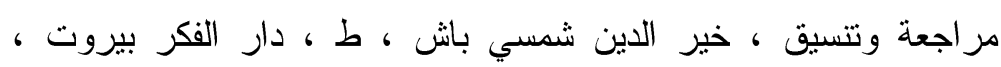

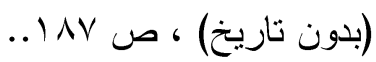

(10) الو افي في العروض و القوافي ، للخطيب التبريزي ، تحقيق: عمر

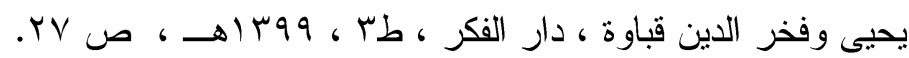

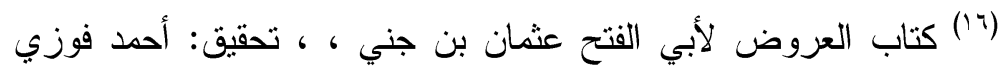

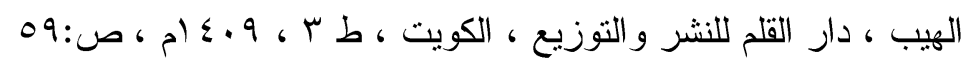

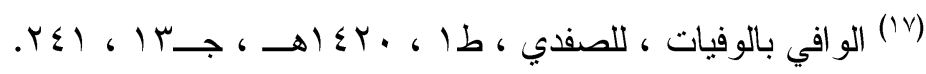
(1) الثافي في علم العروض و القو افي ، هاشم صالح مناع ، دار الفكر

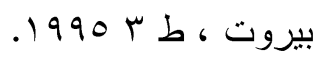

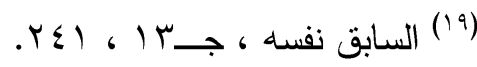


(r.) العروض تهذيبه وإعادة تدوينه ، للشيخ جلال الحنفي ، مطبعة

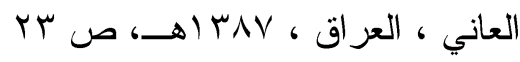

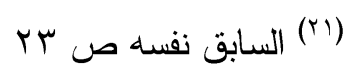

(r) القاموس المحيط ، محمد بن يعقوب الفيروزآبادي ، مطبعة مؤسسة

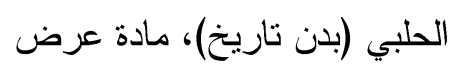

(rr) تاج العروس من جواهر القاموس ، للسيد/ محمد مرتضى الحسيني

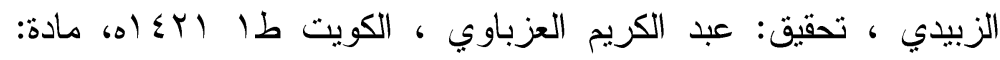

(ro(ro) لسان العرب ، لمحمد بن مكرم بن منظور ، دار الفكر، بيروت ،

$$
\text { (بدون تاريخ) ، مادة عرض برن }
$$

(Yr) على الرغم من تشكلك بعض الباحثين في سبق الخليل إلى معرفة هذه

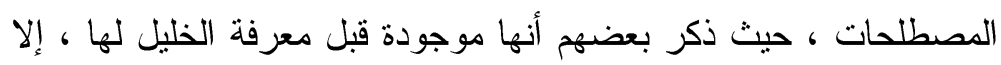
أن الذي بطمئن إليه الباحث أن الخليل هو من عرّن بهذه المصطلحات

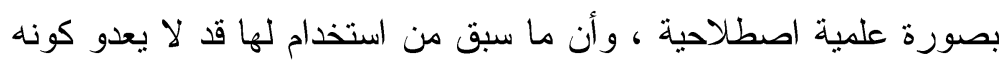

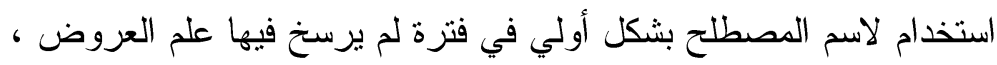
ثم جاء الخليل و ابتدع هذه العلم فرسخت عنده هذه الألفاظ التي كانت

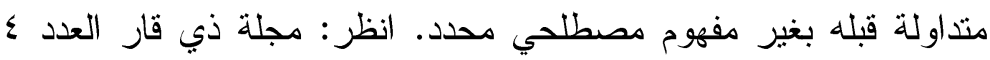

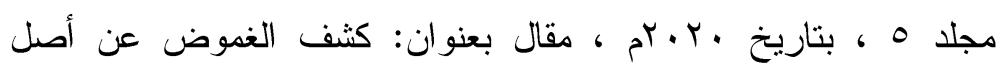

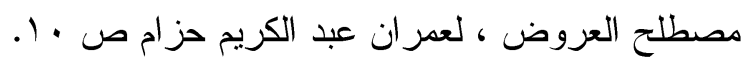

(YV) القسطاس في علم العروض ، جار اله الزمخشري ، تحقيق: د.فخر

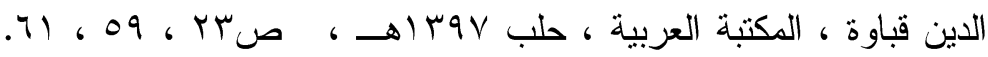

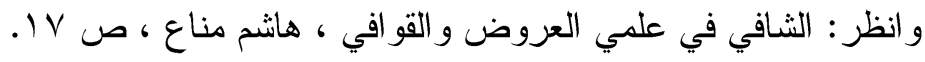




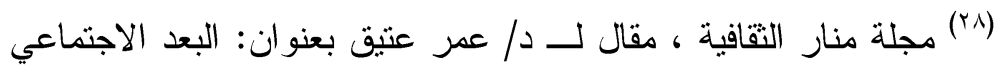

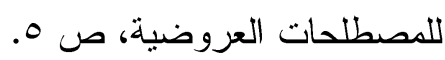
(r9) المزهر في علوم اللغة وآدابها ، مطبعة دار الجيل ، بيروت (بدون

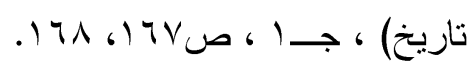

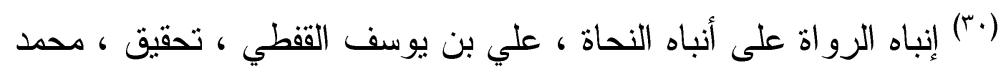

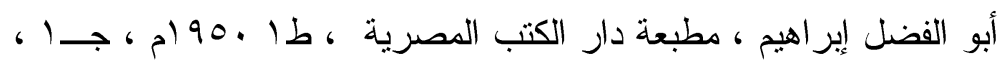
ص T10.

('ا") معيار النظار ، لعبد الوهاب الخزرجي ، ص 11.

(rr) الو افي في العروض و القو افي ، للخطيب التبريزي ، ص اس.

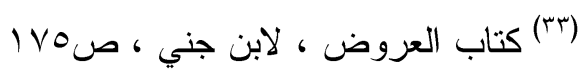

(؛ُ") المعيار في أوزان الأشعار ، لأبي بكر محمد بن عبد الملك بن السراج

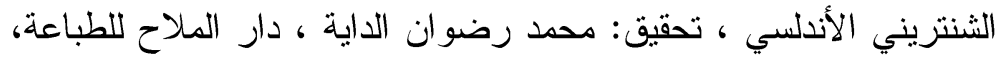

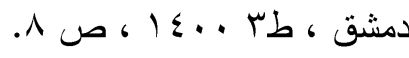

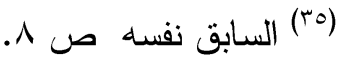
("ץr) القسطاس المستقيم في علم العروش ، لجار اله أبي القاسم محمود بن عمر محمد بن عمر الخوارزمي الزمخري ، تحقيق: بهيجة باقر الحسيني

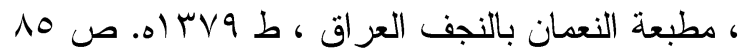

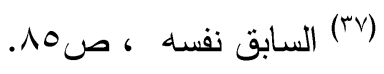

(المعبار في أوزان الأشعار ، لأبي بكر الثنتريني ، ص 9. (ra) جمهرة اللغة ، لابن دريد ، مادة سبب.

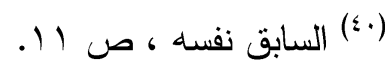


(أ) القاموس المحيط ، للفيروز آبادي ، مادة وتد.

(r) المعيار في أوزان الأشعار ، لأبي بكر الثنتريني ، ص 9. (ז") العروض ، لابن جني ، ص

(؛ §) الحاثية الكبرى ، للسيد محمد الدمنهوري ، مطبعة مصطفى البابي

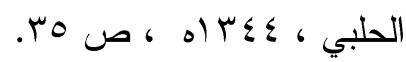
(0) (كذيب اللغة ، مادة: كفأ

(آ؛) السالفة ، خصلة الثعر المرسلة على الخد ـ و الصدغ: ما بين لحاظ

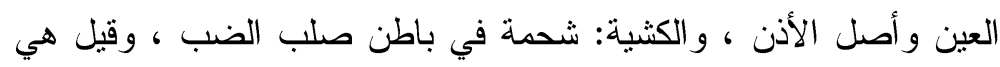

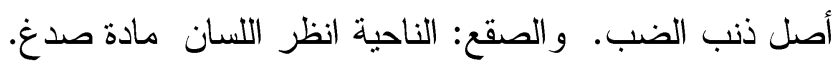

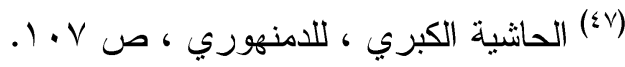

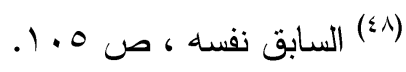

(99) النابغة الذبياني انظر الديوان ، النابغة الذبياني ، تحقيق: محمد أبو

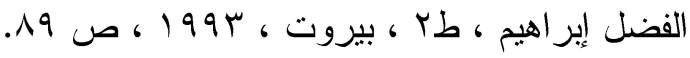
(0.) الثافي في علمي العروض و القو افي ، لهاثم مناع ، ص 109. (1) لسان العرب ، لابن منظور ، مادة رمل (أمعيار في أوزان الأشعار ، للشنتريبي ، ص م. أم. (Or) معيار النظار في علوم الأشعار ، للزنجاني ، ، جـ ، 1 ، ص |' .

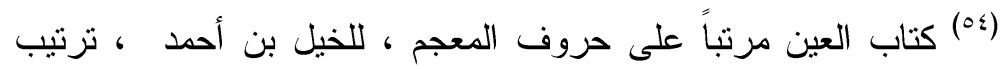

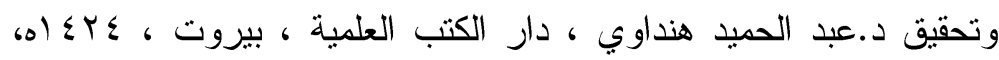

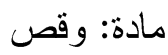




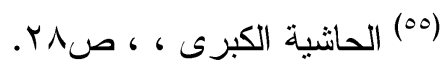

(7) لسان العرب ، مادة وقص ، و انظر المادة نفسها في مختار الصحاح

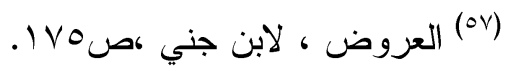

(01) معيار النظار ، للخزرجي ، جـ ، ص سا. (09) الحاثشية الكبرى ، للدمنهوري ، ص Vس.

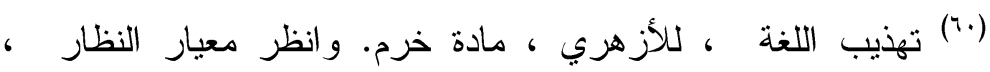

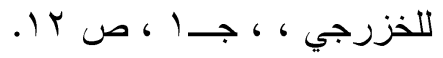

('اי) معيار النظار ، للخزرجي ، جـ! ، صץ|.

(ז'معيار النظار للخزرجي ، جـ1 ، با.

(זי) معيار النظار ، للخزرجي جـ1 ، با.

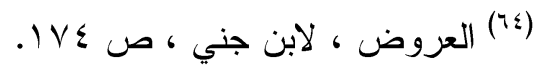

(70) معيار النظار للخزرجي ، جـ 1 ، سا.

(Tr) الو افي في العروض و القو افي ، للخطيب التبريزي ، ص YYV.

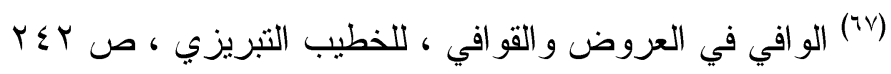

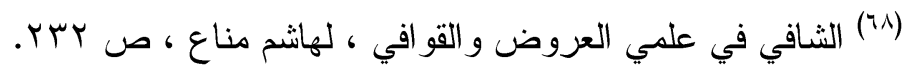

(79) الو افي في العروض و القو افي ، للخطيب التبريزي ، ص Yrr.

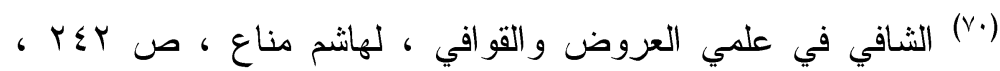
و انظر اللسان ، مادة: نهك. 


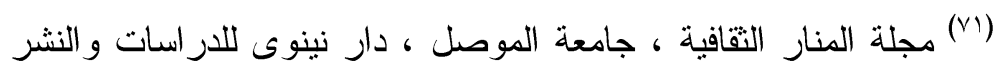

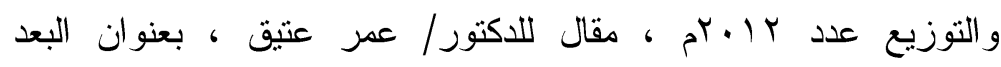
الاجتماعي للمصطلحات العروضية ، صن مدربع IV ك كتاب العروض ، لابن جني ، صrr) (Vr)

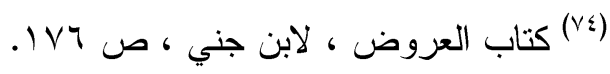

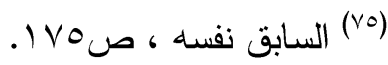

(VT) الحاثية الكبرى ، للدمنهوري ، ص عس. ( الحاشية الكبرى ، للدمنهوري ، ص عَ. (vV) كتاب العروض ، لأبي الفتح عثمان بن جني ، ص ع V V ا. (v9) تهذيب اللغة ، للأزهري ، مادة زحف.

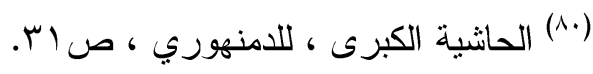

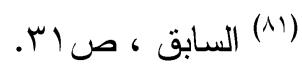
(Ar) الثافي في علمي العروض و القو افي ، لهاتم مناع ، ص • ؟r. (^r) معيار النظار ، للخزرجي ، جـ ( ، ص سا. ل (10) الحاثنية الكبرى ، للدمنهوري ، صهץ. (T) معيار النظار ، للخزرجي، جـا ، ص سا. لسان العرب ، لابن منظور ، مادة جمم. (Av) 
(^^) كتاب العروض ، لابن جني ، ص AV.

(199) (الحاثية الكبرى ، للامنهوري ، ص عس.

(9.( الصحاح في اللغة ، للجوهزي ، مادة خزم.

(1) كتاب العروض ، لابن جني ص س IVI.

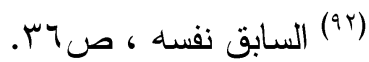

(9r) لسان العرب ، لابن منظور ، مادة: رجز

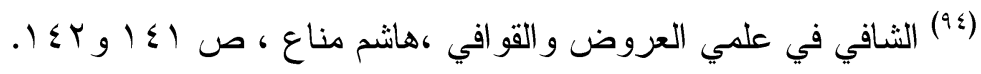

(90) (السابق نفسه ، ص سبا.

(97) اللسان ، لابن منظور ، مادة هزج

(9V) ديو ان رؤبة بن العجاج ، طبعة ليسبغ ب. 9 ام ، ص101.

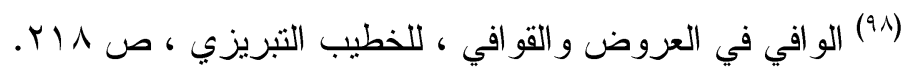

